\title{
Material Exchange and Migration between Pore Fluids and Sandstones during Diagenetic Processes in Rift Basins: A Case Study Based on Analysis of Diagenetic Products in Dongying Sag, Bohai Bay Basin, East China
}

\author{
W. Meng, ${ }^{1,2}$ J. H. Zeng ${ }^{(D)},{ }^{1,2}$ Z. Cao, ${ }^{1,2}$ G. Q. Song, ${ }^{3}$ Y. S. Wang, ${ }^{3}$ J. L. Teng, ${ }^{1,2}$ and Z. Guo ${ }^{1,2}$ \\ ${ }^{1}$ State Key Laboratory of Petroleum Resources and Prospecting, Beijing, China \\ ${ }^{2}$ College of Geosciences, China University of Petroleum, Beijing, China \\ ${ }^{3}$ Shengli Oilfield Branch Company, Sinopec, Dongying, China \\ Correspondence should be addressed to J. H. Zeng; zengjh@cup.edu.cn
}

Received 30 June 2017; Revised 15 December 2017; Accepted 28 December 2017; Published 15 February 2018

Academic Editor: Jet-Chau Wen

Copyright @ 2018 W. Meng et al. This is an open access article distributed under the Creative Commons Attribution License, which permits unrestricted use, distribution, and reproduction in any medium, provided the original work is properly cited.

\begin{abstract}
The exchange and migration of basin materials that are carried by pore fluids are the essence of diagenesis, which can alter physical properties of clastic rocks as well as control formation and distribution of favorable reservoirs of petroliferous basins. Diagenetic products and pore fluids, resulting from migration and exchange of basin materials, can be used to deduce those processes. In this study, 300 core samples from 46 wells were collected for preparation of casting thin sections, SEM, BSE, EDS, inclusion analysis, and isotope analysis in Dongying Sag, Bohai Bay Basin, East China. Combined with geochemical characteristics of pore fluids and geological background of the study area, the source and exchange mechanisms of materials in the pore fluids of rift basins were discussed. It was revealed that the material exchange of pore fluids could be divided into five stages. The first stage was the evaporation concentration stage during which mainly $\mathrm{Ca}^{2+}, \mathrm{Mg}^{2+}$, and $\mathrm{CO}_{3}{ }^{2-}$ precipitated as high-Mg calcites. Then came the shale compaction stage, when mainly $\mathrm{Ca}^{2+}$ and $\mathrm{CO}_{3}{ }^{2-}$ from shale compaction water precipitated as calcites. The third stage was the carboxylic acid dissolution stage featured by predominant dissolution of plagioclases, during which $\mathrm{Ca}^{2+}$ and $\mathrm{Na}^{+}$entered pore fluids, and $\mathrm{Si}$ and $\mathrm{Al}$ also entered pore fluids and then migrated as clathrates, ultimately precipitating as kaolinites. The fourth stage was the organic $\mathrm{CO}_{2}$ stage, mainly characterized by the kaolinization of K-feldspar as well as dissolution of metamorphic lithic fragments and carbon cements. During this stage, $\mathrm{K}^{+}, \mathrm{Fe}^{2+}, \mathrm{Mg}^{2+}, \mathrm{Ca}^{2+}, \mathrm{HCO}_{3}{ }^{-}$, and $\mathrm{CO}_{3}{ }^{2-}$ entered pore fluids. The fifth stage was the alkaline fluid stage, during which the cementation of ferro-carbonates and ankerites as well as illitization or chloritization of kaolinites prevailed, leading to the precipitation of $\mathrm{K}^{+}, \mathrm{Fe}^{2+}, \mathrm{Mg}^{2+}, \mathrm{Ca}^{2+}$, and $\mathrm{CO}_{3}{ }^{2-}$ from pore fluids.
\end{abstract}

\section{Introduction}

Pore fluids mainly refer to all fluids that occupy and pass through the pore space of sedimentary basins [1,2]. During the burial process, basin materials could be loaded and redistributed by pore fluids. Those processes could lead to regularly distributed diagenetic products in basins [3]. Formation and evolution of diagenetic products could result in preservation or destruction of primary pores as well as formation and transformation of secondary pores, which could significantly influence the formation and occurrence of effective reservoirs in the deep part of petroliferous basins
[4-16]. Previous studies mainly highlighted evolution of physical properties of clastic rocks and primarily investigated diagenetic facies and sequences based on sedimentological and petrological analyses [11, 17-26]. However, insufficient attention was paid to the nature of diagenesis, namely, the exchange and migration of basin materials loaded by pore fluids. Meanwhile, many controversies arose concerning the formation mechanism of secondary pores, which further obscured prediction of distribution of secondary pores and effective reservoirs $[5,14,23,27-34]$. Therefore, it should be critical to figure out the mechanism of basin material exchange and migration during the diagenetic process so as to 
analyze the formation and distribution of diagenetic products and favorable sandstone reservoirs.

During diagenetic process, matrix of clastic rocks could be transformed or dissolved, and materials might partly or totally enter into pore fluids as ions or complexes. Solutes (ions or complexes) carried by pore fluids could be deposited as cements under appropriate geological conditions. In these processes, compositions of clastic rocks and chemical properties of pore fluids could be changed. These changes could be used to infer material exchange and migration mechanisms during diagenesis.

\section{Geological Setting}

Dongying Sag is a subtectonic unit in the southeastern of Jiyang Depression, Bohai Bay Basin (Figure 1) [35]. It can be further subdivided into six secondary tectonic zones, known as Northern Steep Slope Zone, Lijin Subsag, Minfeng Subsag, Central Anticline Zone, Niuzhuang Subsag, and Southern Gentle Slope Zone (Figure 1) [35].

There are mainly three sets of successions in the Dongying Sag, namely, Paleogene, Neogene, and Quaternary. The Paleogene mainly comprises Kongdian (Ek), Shahejie (Es), and Dongying (Ed) Formations; the Neogene Guantao (Ng) and Minghuazhen (Nm) Formations; and the Quaternary Pingyuan (Qp) Formation (Zhai and He 1993) [36]. There is a main regional unconformity serving as the boundary between Ed and Ng Formations (Figure 2) (Zhai and He 1993) $[35,36]$. Shahejie Formation can be subdivided into four members, namely, Es4, Es3, Es2, and Es1, from base to top [36]. This study focused on the Es4 and Es3 members.

Es4 consists of gray and dark-gray mudstones, gypsum and halite, interbedded nearshore subaqueous fan sandstones, and sublacustrine fan sandstones deposited in semideep and deep lacustrine environments, which are mainly located in the Northern Steep Slope Zone. The lower submember of Es3 $\left(E s 3^{3}\right)$ was deposited in semideep and deep lacustrine environments, dominated by lacustrine oil shales, dark-gray mudstones, calcareous mudstones, and subaqueous (sublacustrine) fan sandstones in terms of lithology. The middle submember of Es3 (Es3 ${ }^{2}$ ) consists of gray to darkgray mudstones, calcareous mudstones, subaqueous (sublacustrine) fan sandstones, and delta sandstones deposited in semideep and deep lacustrine environments. The upper submember of Es3 $\left(\right.$ Es $\left.^{1}{ }^{1}\right)$ is dominated by deltaic sandstones.

\section{Samples and Methods}

A total of 1472 thin sections were collected, which were prepared from the Es core samples in the Dongying Sag by Geological Scientific Research Institute of China Sinopec Shengli Oilfield Company, where 1423 data about Es formation water chemical composition were also collected.

A total of 300 blue epoxy resin-impregnated thin sections were prepared for diagenesis analysis using the Es drill cores of 46 wells in Dongying Sag. This study focused on the type, occurrence, content, and contact metasomatic relationship of diagenetic products. With at least 300 points, estimations of component contents by point accounting can be more reliable with a standard deviation less than 5.5\%. 40 out of 300 samples were implemented with EBSD, SEM, and EDX analysis in order to investigate chemical characteristics of authigenic kaolinites and carbon cements. 34 out of 300 samples showed only one type of carbon cements, and they were selected for analysis of $\delta^{13} \mathrm{C}_{\mathrm{V}-\mathrm{PDB}} / \%$ and $\delta^{18} \mathrm{O}_{\mathrm{V}-\mathrm{PDB}} / \%$. The collection of carbon cements from these samples was taken at the Institute of Mineral Resources and Regional Geology of Hebei Province, while the measurement of $\delta^{13} \mathrm{C}_{\mathrm{V}-\mathrm{PDB}} / \%$ and $\delta^{18} \mathrm{O}_{\mathrm{V}-\mathrm{PDB}} / \%$ was completed using Gas Isotope Ratio Mass Spectrometry (MAT 253) at Chinese Academy of Geological Sciences. Fluid inclusion analysis was carried out on 14 samples, which were prepared as doubly polished sections with approximate thicknesses of $100 \mathrm{~mm}$ for fluid inclusion petrographic analysis and thermometric measurement. Microthermometry of aqueous inclusions was conducted using calibrated Linkam-350, during which the homogenization temperature (Th) was obtained by cycling and $\mathrm{Th}$ measurements were completed with a heating rate of $10^{\circ} \mathrm{C} / \mathrm{min}$ when the temperature was lower than $70^{\circ} \mathrm{C}$, and $5^{\circ} \mathrm{C} /$ min when the temperature exceeded $70^{\circ} \mathrm{C}$. The precision of measured $\mathrm{Th}$ was within $\pm 1^{\circ} \mathrm{C}$. A total of 592 data concerning bulk rock and clay mineral analyses were collected from Geological Scientific Research Institute of China Sinopec Shengli Oilfield Company, which were mainly to identify the distribution of contents of different clay minerals.

\section{Results}

4.1. Detrital Composition of Es Sandstones. Es sandstones in Dongying Sag are medium to fine grained arkoses and lithic arkoses (av. $\mathrm{Q}_{47.4} \mathrm{~F}_{33.8} \mathrm{~L}_{18.7}$; Figure 3 ). They are poorly to moderately sorted and subangular, with the matrix content of 1.7-13.6\%. It was revealed by thin section observation that the quartz grains in those sandstones (av. 39.8\%) were mainly monocrystalline quartz (av. 39.0\%) and, less commonly, polycrystalline quartz (av. 0.8\%). Es3 sandstones had the highest content of quartz grains (av. 43.2\%), while Es1 sandstones had the lowest (av. 39.5\%). The feldspar particles in those sandstones (av. 15.1\%) were mainly K-feldspar (av. 9.0\%) and, less commonly, plagioclase (av. 6.1\%). Es1 sandstones had the highest content of feldspar particles (av. 20.2\%), while Es3 sandstones had the lowest (av. 12.2\%). The content range of lithic fragments in those sandstones was relatively large, 1.7-53.2\%. Lithic fragments in Es sandstones were all dominated by metamorphic lithic fragments. The difference is that the amount of igneous and sedimentary lithic fragments was relatively higher in the Es1 and Es2 sandstones, but relatively lower in Es3 and Es4 sandstones (Table 1).

During the burial process, the interaction between pore fluids and grains in sandstones could result in the changes of type and content of clastic particles. In the sandstones with depth less than $3200 \mathrm{~m}$, the content of quartz particles increased significantly, and the content of feldspar grains decreased dramatically, with the increase of depth. However, such trend was opposite in sandstones with depth more than $3200 \mathrm{~m}$. Moreover, it was found that the content of lithic fragments kept relatively unchanged until the depth reached $2800 \mathrm{~m}$, after which it sharply decreased with depth 


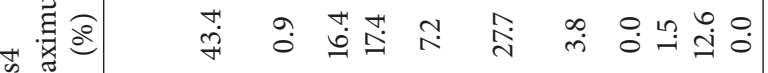

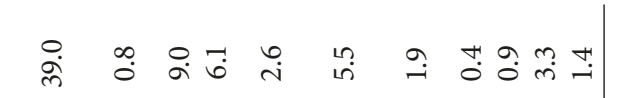
(1)

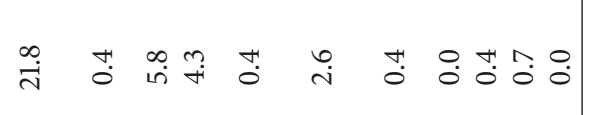

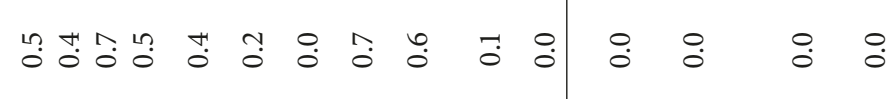

䑻

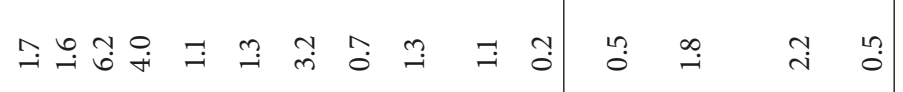

ஷ̊

$\stackrel{m}{\infty} \stackrel{\infty}{\sim} \stackrel{m}{m}$

$\stackrel{n}{4}$

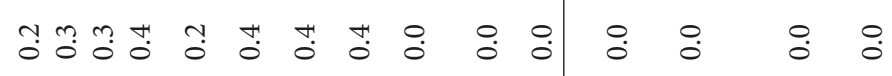

苋

敬

$$
\ddot{m}
$$

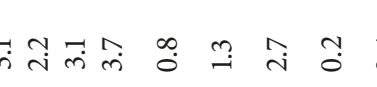

(1)

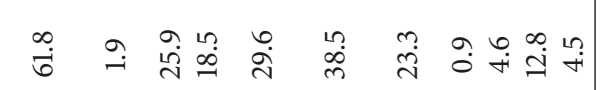

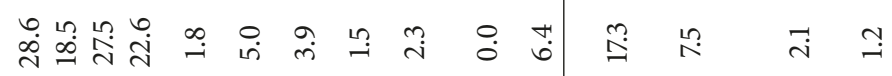
क

査

它

ชุอง

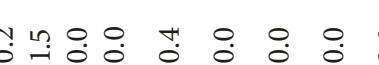

$+$

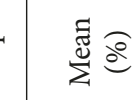

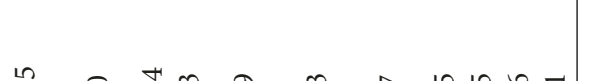

กี

ㅁํ ㄱํำ

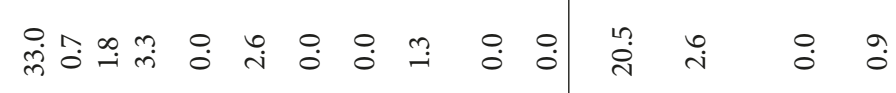

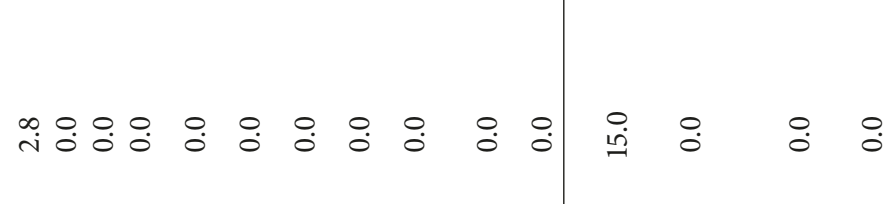

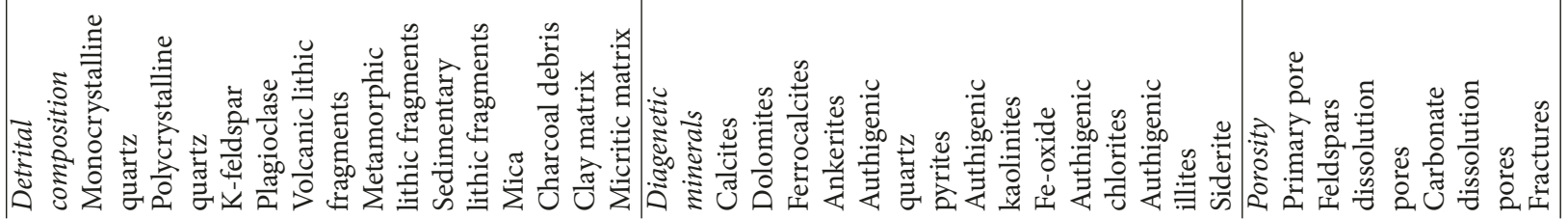




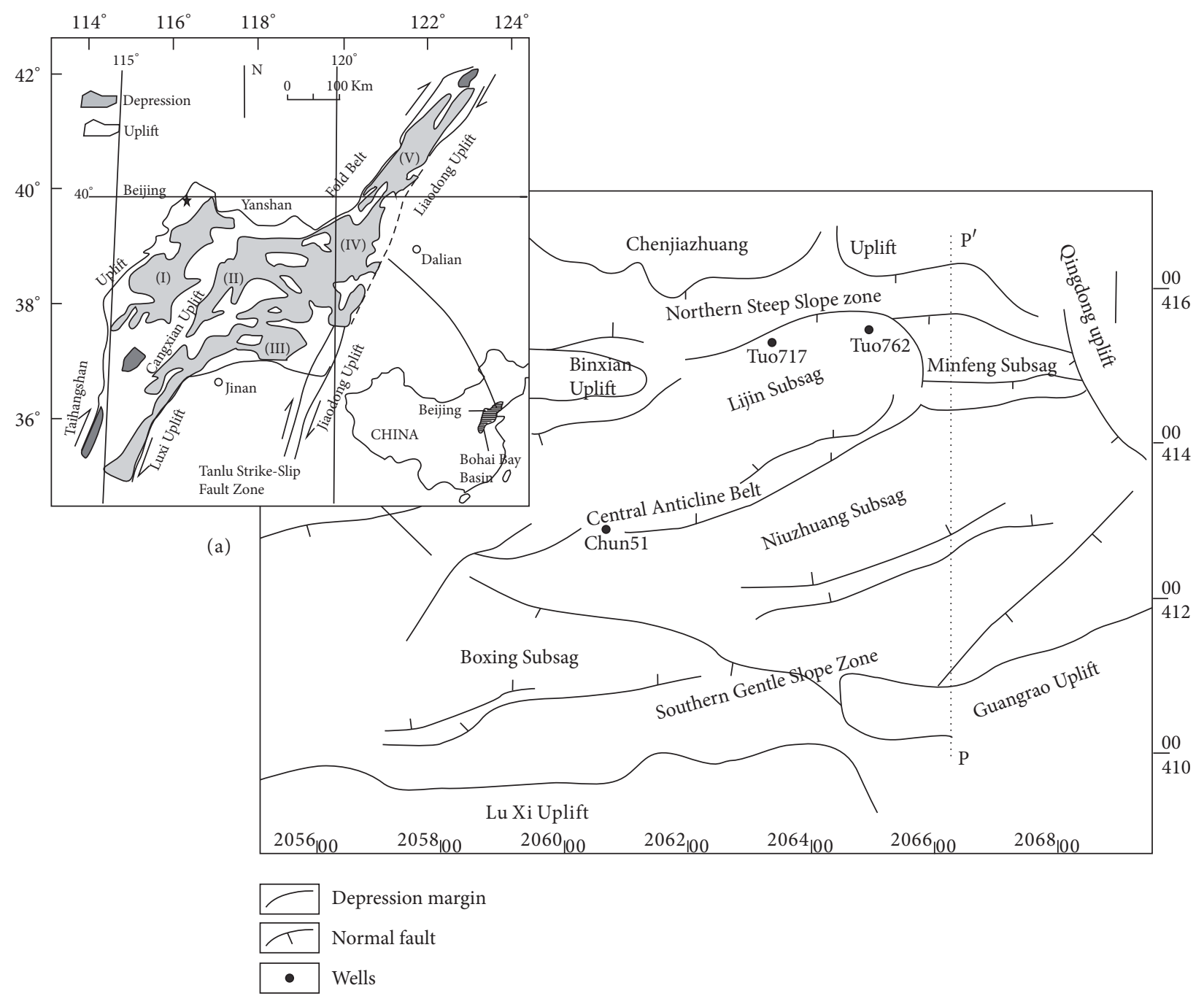

(b)

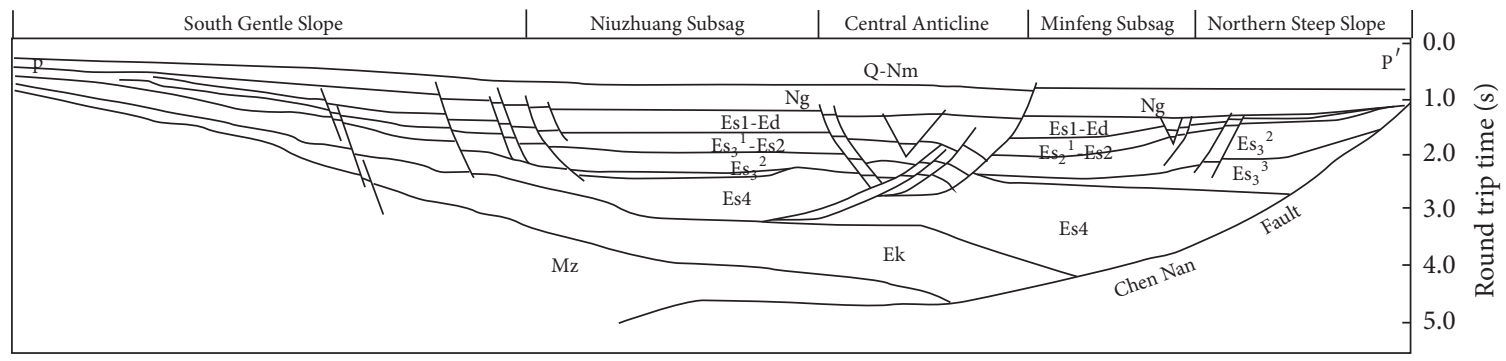

(c)

Figure 1: Location map and cross section of the study area. (a) Location map of the study area showing the subtectonic units of the Bohai Bay Basin, namely, Jizhong Depression (I), Huanghua Depression (II), Jiyang Depression (III), Bozhong Depression (IV), and Liaohe Depression (V). (b) Structural map of the Dongying Sag. (c) N-S cross section $\left(\mathrm{P}^{\prime}-\mathrm{P}\right)$ of the Dongying Sag showing the various tectonic-structural zones and key stratigraphic intervals [35].

(Figure 4). In addition, in the depth less than $2800 \mathrm{~m}$, the proportion of different lithic fragments in total lithic fragments was relatively constant, which, however, changed when the depth reached $2800 \mathrm{~m}$. To be specific, the proportion of igneous lithic fragments increased with depth, while that of metamorphic lithic fragments decreased (Figure 4). Similarly, the proportion of anorthose grains in total feldspar grains declined with depth, while that of $\mathrm{K}$-feldspar grains increased, when the depth was less than $2800 \mathrm{~m}$ (Figure 4). However, in sandstones with depth from $2800 \mathrm{~m}$ to $3200 \mathrm{~m}$, 


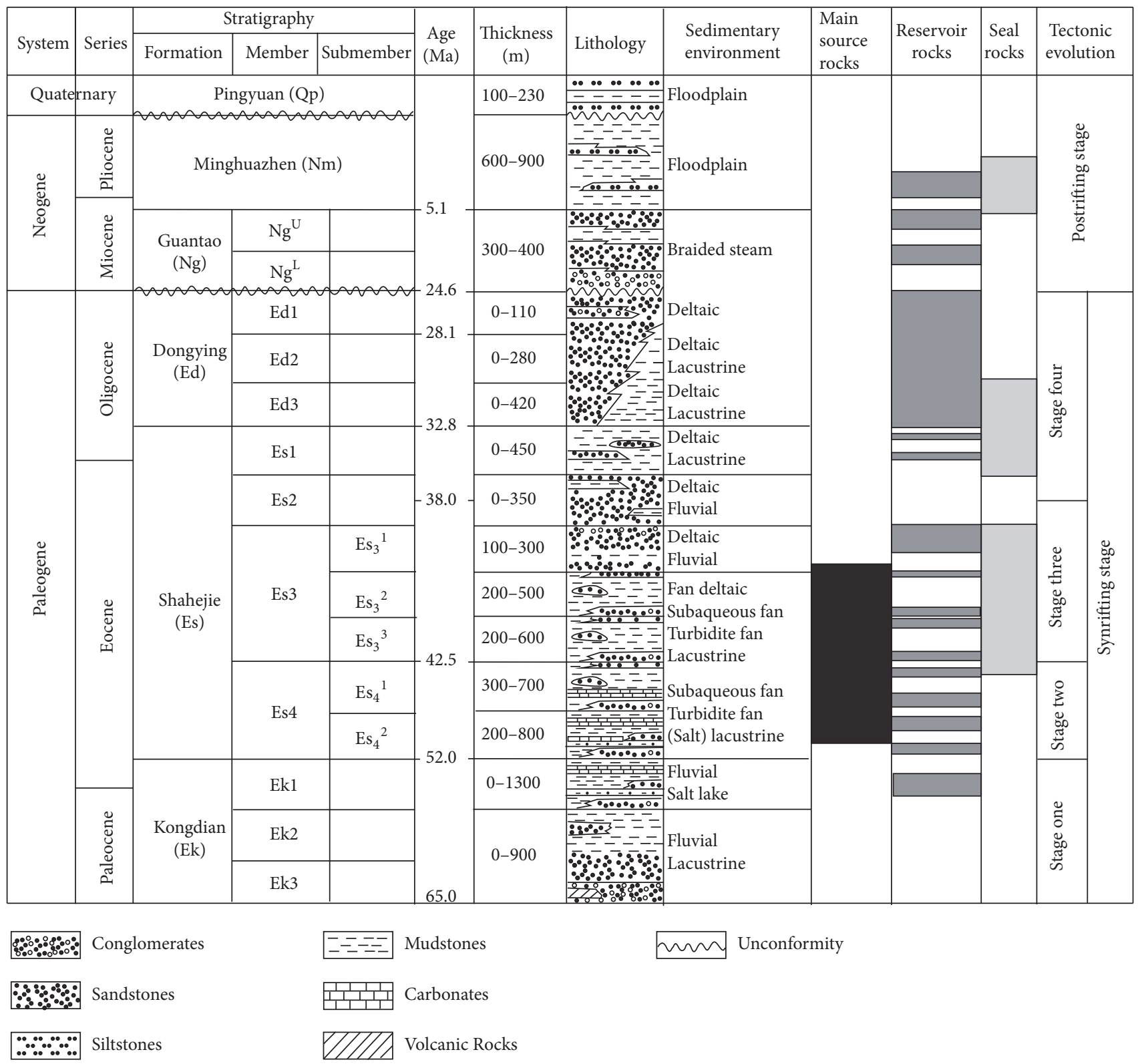

FIgURE 2: Generalized Cenozoic-Quaternary stratigraphy of the Dongying Sag (modified from [35]).

the trend was opposite, which meant increasing anorthose grains and decreasing $\mathrm{K}$-feldspar grains with depth. As for the sandstones buried deeper than $3200 \mathrm{~m}$, contents of anorthose and K-feldspar rarely changed (Figure 4).

\subsection{Chemical Characteristics of Formation Water in Dongying} Sag. The major elements of formation water were found to change regularly with depth in Dongying Sag. The contents of $\mathrm{Na}^{+}$and $\mathrm{K}^{+}$increased in the depth ranges of $2200 \mathrm{~m}-2500 \mathrm{~m}$ and $2800 \mathrm{~m}-3400 \mathrm{~m}$, respectively, reaching the maximum at the depth of $3400 \mathrm{~m}$ and then slightly declining. The content of $\mathrm{Cl}^{-}$increased with depth from $2200 \mathrm{~m}$, achieving the maximum and remaining stable after the depth exceeded $2500 \mathrm{~m}$. The content of $\mathrm{Ca}^{2+}$ greatly increased with depth in the range of $2200 \mathrm{~m}-3200 \mathrm{~m}$, reaching the maximum at $3200 \mathrm{~m}$ and then dropping greatly with depth. The content of $\mathrm{HCO}_{3}{ }^{-}$increased in the range of $2500 \mathrm{~m}-3000 \mathrm{~m}$, achieving the maximum at $3000 \mathrm{~m}$ and then decreasing greatly with depth. The content of $\mathrm{CO}_{3}{ }^{2-}$ increased with depth after the depth exceeded $2800 \mathrm{~m}$ (Figure 5).

4.3. Morphological, Geochemical, and Distribution Features of Diagenetic Products in Es Sandstones. Pore fluids in Es sandstones experienced multiphase material exchange and migration, leading to the formation and evolution of diagenetic products. These diagenetic products mainly included carbonate cements; quartz cements; aluminosilicate minerals such as kaolinite, illite, and chlorite; opaque minerals such 


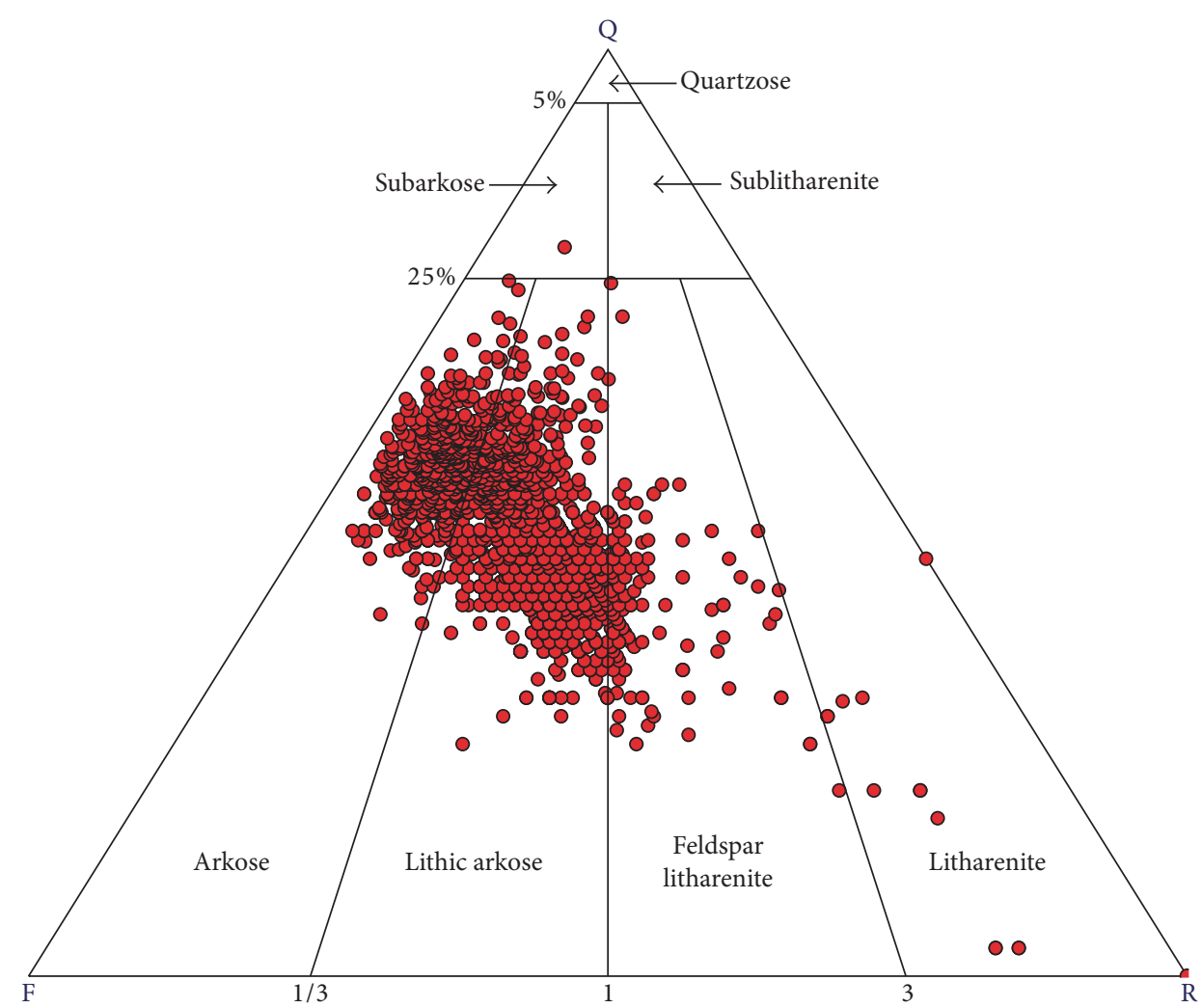

FIGURE 3: Detrital composition of sandstone samples of 1472 samples from the Es sandstones in Dongying Sag.

as pyrite; dissolution pores of unstable particles (feldspar and lithic fragments) and carbonate cements. The contents of different diagenetic products varied greatly in the sandstones of different members of Es. The contents of carbonate cements were relatively higher in Es3 and Es4 sandstones (av. 13.5\% and av. 13.4\%, resp.), while that in Es1 sandstones was relatively lower (av. 8.1\%). The carbonate cements in Es1 sandstones were mainly calcite; those in Es2 sandstones calcite, dolomite, ferrocalcite, and ankerite; those in Es3 sandstones mainly ferrocalcite and ankerite; and those in Es4 sandstones mainly dolomite and ankerite. Quartz cements were mainly observed in sandstones of Es2, Es3, and Es4, with rare observations of them in Es1 sandstones. Authigenic kaolinites were mainly found in Es2 and Es3 sandstones, while few of them were observed in sandstones of Es1 and Es4. Feldspar dissolution pores were predominantly in sandstones of Es2, Es3, and Es4, and they were most developed in Es3 sandstones. Es3 and Es4 sandstones were main hosts to carbonate cement dissolution pores, and Es4 sandstones had the largest amount of carbonate cement dissolution pores (Table 1).

4.3.1. Distribution and Geochemical Features of Carbonate Cements with Different Morphologies. There were mainly four stages of carbonate cements with different morphologies in the study area. Carbonate cements of the first stage (Ccl) were generally isopachous on the surface of particles (Figures 6(a) and 6(b)), occurring in sandstones with depth ranging from $1700 \mathrm{~m}$ to $3600 \mathrm{~m}$ (Figure 7). They were only observed in a few sandstone samples. Carbonate cements of the second stage (Cc2) were mainly medium-coarse crystalline calcite, filling the primary pores which were not obviously affected by compaction. This type of carbonate cements was generally on the outer side of Cc1 (Figures 6(a), 6(b), and 6(c)), and they usually occurred in sandstones with depth ranging from $1700 \mathrm{~m}$ to $3600 \mathrm{~m}$, concentrated in the depth range of $1700-2800 \mathrm{~m}$. From $2800 \mathrm{~m}$ to $3600 \mathrm{~m}$, Cc2 was obviously dissolved (Figure 7). Carbonate cements of the third stage $(\mathrm{Cc} 3)$ filled in residual primary pores after compaction as well as feldspar dissolution pores (Figures 6(e) and 6(f)). They generally occurred in the sandstones with depth ranging from $2000 \mathrm{~m}$ to $3600 \mathrm{~m}$, concentrated in the range of $2100 \mathrm{~m}$ to $2700 \mathrm{~m}$. The content of Cc3 decreased greatly with depth once the depth reached $2700 \mathrm{~m}$ (Figure 7). Carbonate cements of the fourth stage ( $\mathrm{Cc} 4)$ were euhedral fine crystalline ferrocalcites and ankerites, lying on the outer part of kaolinization feldspar or secondary pores dissolved by Cc3 (Figures 6(g) and $6(\mathrm{~h})$ ). They were mainly found in the sandstones with the depth over $3100 \mathrm{~m}$, and their content increased greatly with depth (Figure 7).

$\mathrm{Ccl}$ was mainly micritic high- $\mathrm{Mg}$ calcite $\left(\mathrm{CaCO}_{3} 71-79 \%\right.$; $\mathrm{MgCO}_{3}$ 15-23\%; $\mathrm{FeCO}_{3} 2-5 \% ; \mathrm{MnCO}_{3}$ 0-2\%) (Figure 8). It was difficult to obtain isotope data from $\mathrm{Ccl}$, due to its low content. $\mathrm{Cc} 2$ was mainly calcite $\left(\mathrm{CaCO}_{3}\right.$ 91-100\%; $\mathrm{MgCO}_{3} \quad 0-5 \% ; \mathrm{FeCO}_{3} \quad 0-5 \% ; \mathrm{MnCO}_{3}$ 0-2\%) (Figure 8), with $\delta^{13} \mathrm{C}_{\mathrm{V}-\mathrm{PDB}} / \%$ values from $+1.60 \%$ o to $+3.50 \%$ (av. $2.76 \%$ o ) and $\delta^{18} \mathrm{O}_{\mathrm{V}-\mathrm{PDB}} / \%$ values from $-12.40 \%$ o to $-9.10 \%$ o (av. $-10.33 \%$ ) (Figure 9). The chemical composition of Cc3 


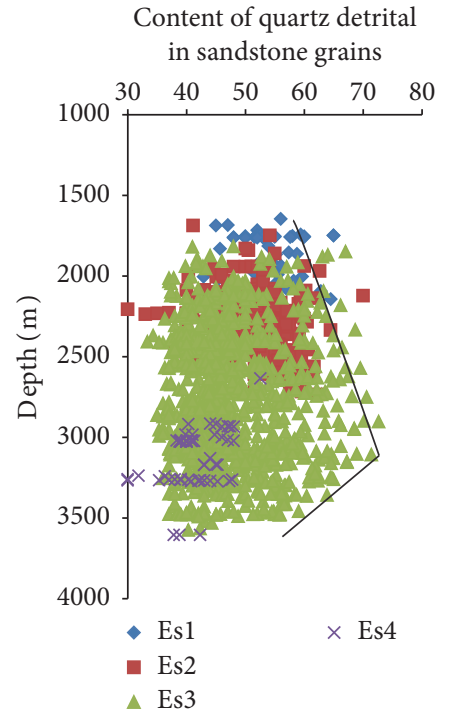

Content of sedimentary cutting grains grains in total cutting grains
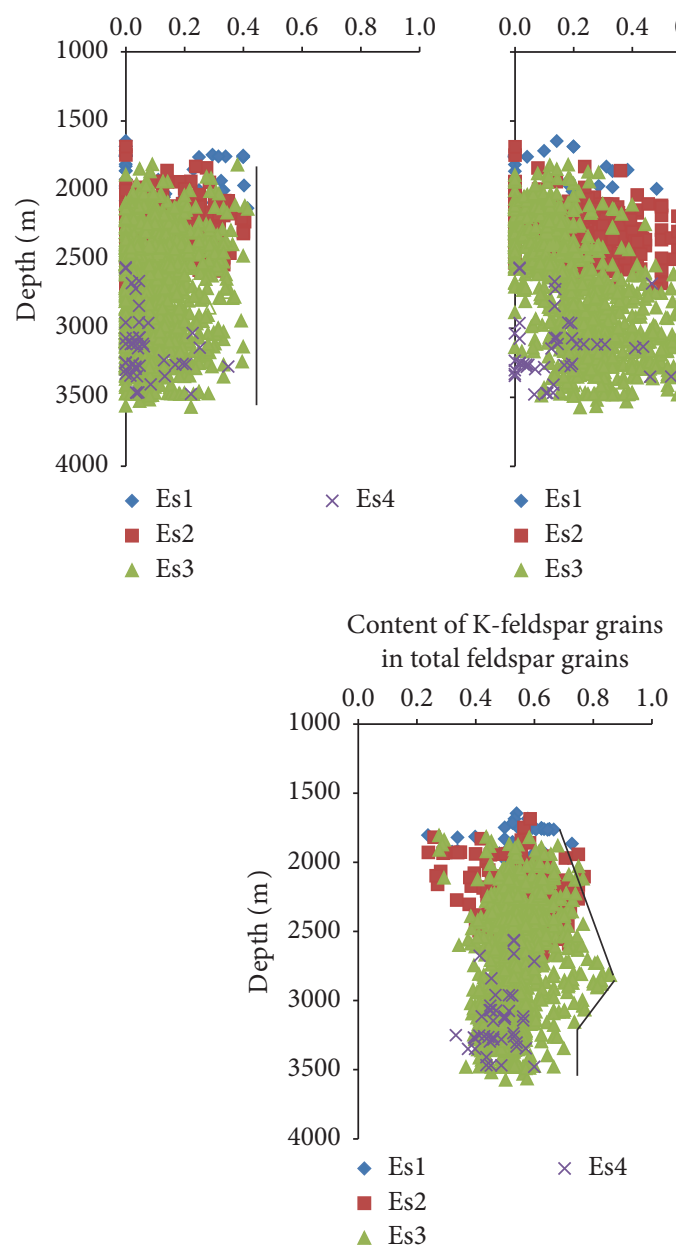

Content of cutting grains in sandstone grains

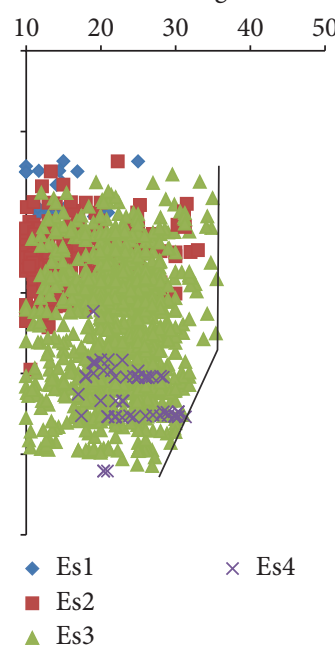

Content of igneous cutting grains in total cutting grains
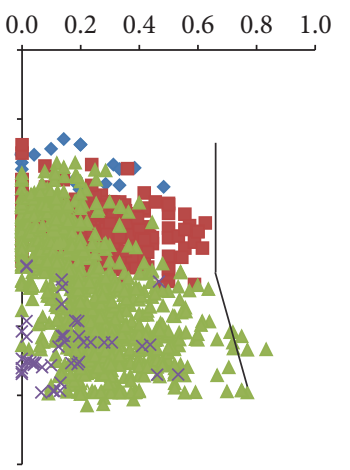

- Es1 $\quad \times$ Es4

Es2

$\triangle$ Es3
Content of feldspar grains in sandstone grains

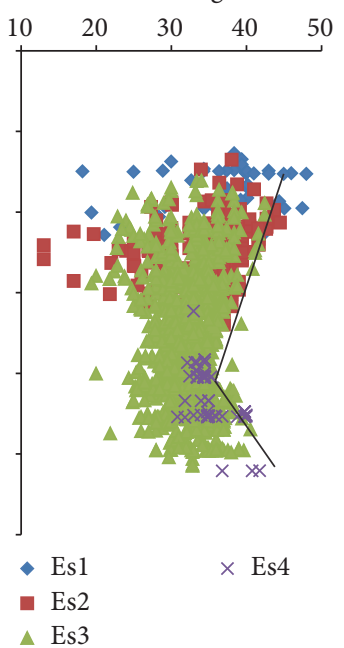

Content of metamorphic cutting grains grains in total cutting grains

$\begin{array}{llllll}0.0 & 0.2 & 0.4 & 0.6 & 0.8 & 1.0\end{array}$

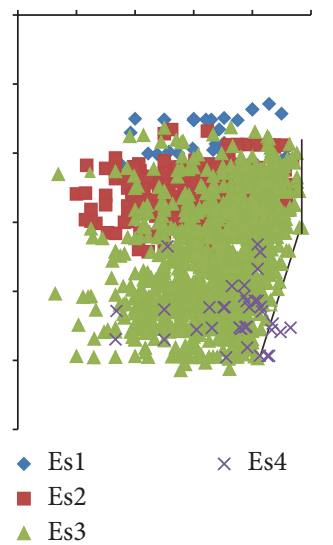

Content of plagioclase grains in total feldspar grains $\begin{array}{llllll}0.0 & 0.2 & 0.4 & 0.6 & 0.8 & 1.0\end{array}$

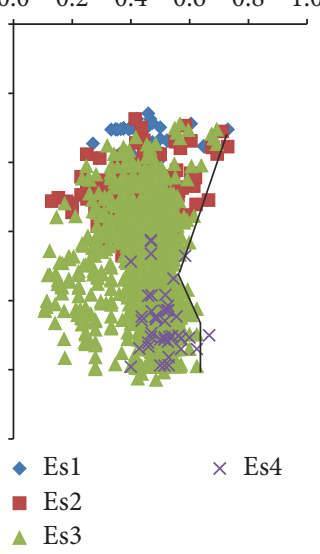

Figure 4: The content changes of different grains in sandstones of Es in Dongying Sag. 

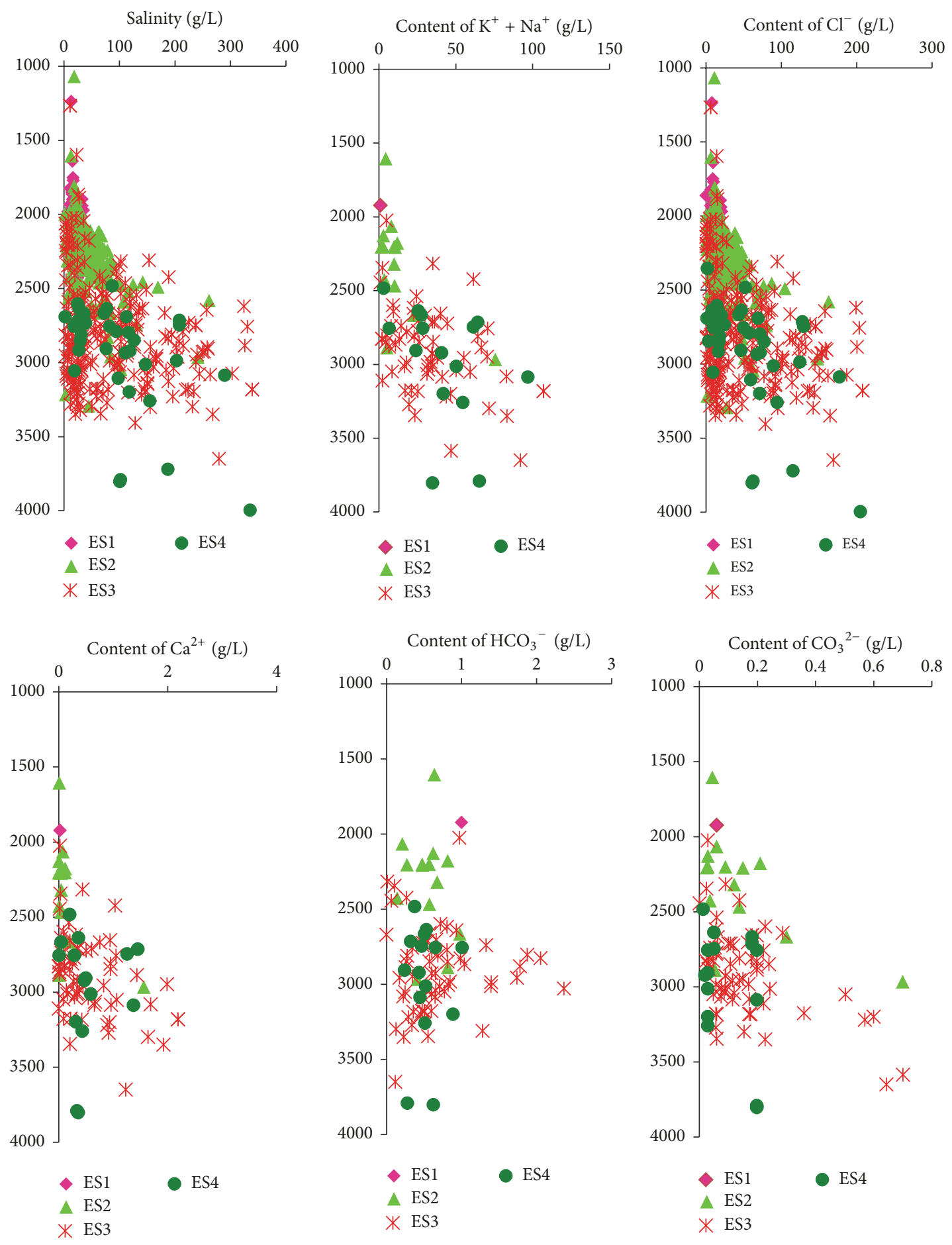

FIGURE 5: Changes of chemical characteristics of formation water with depth in Dongying Sag.

was complicated $\left(\mathrm{CaCO}_{3} 43-97 \% ; \mathrm{MgCO}_{3} 0-54 \% ; \mathrm{FeCO}_{3}\right.$ $1-11 \%$; $\mathrm{MnCO}_{3} 0-4 \%$ ) (Figure 8), and it had a relatively wide range of $\delta^{13} \mathrm{C}_{\mathrm{V}-\mathrm{PDB}} / \%$ values from $-6.60 \%$ to $+4.30 \%$ (av. $1.03 \%$ ) and $\delta^{18} \mathrm{O}_{\mathrm{V}-\mathrm{PDB}} / \%$ values from $-13.90 \%$ to $-5.10 \%$ o (av. $-11.00 \%$ ) (Figure 9). Cc4 had higher contents of $\mathrm{Fe}$ and $\mathrm{Mn}\left(\mathrm{CaCO}_{3} 38-83 \% ; \mathrm{MgCO}_{3} 3-53 \%\right.$; $\mathrm{FeCO}_{3}$ 6-14\%; $\mathrm{MnCO}_{3} 0-7 \%$ ) (Figure 8), with the $\delta^{13} \mathrm{C}_{\mathrm{V}-\mathrm{PDB}} / \%$ values from
$-6.40 \%$ to $-3.30 \%$ o (av. $-4.85 \%$ ), and $\delta^{18} \mathrm{O}_{\mathrm{V}-\mathrm{PDB}} / \%$ v values from $-15.90 \%$ to $-13.50 \%$ (av. $-14.70 \%$ ) (Figure 9).

4.3.2. Distribution of Quartz Cementation with Different Morphologies and Fluid Inclusions. Three types of quartz cementation could be identified according to the morphology, respectively, in forms of quartz overgrowth, micro- to 


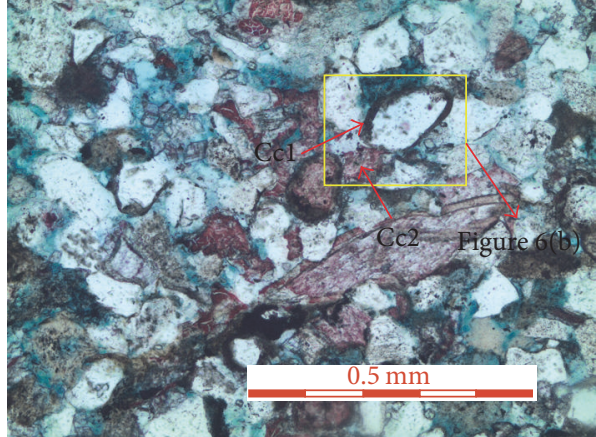

(a)

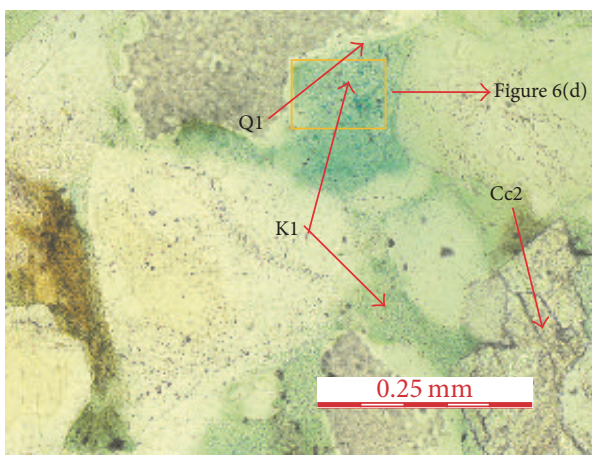

(c)

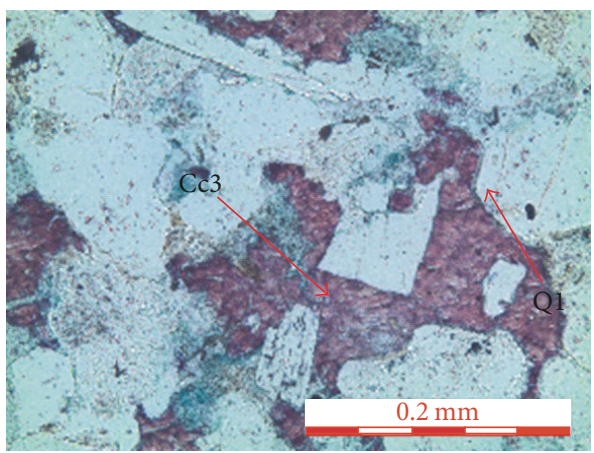

(e)

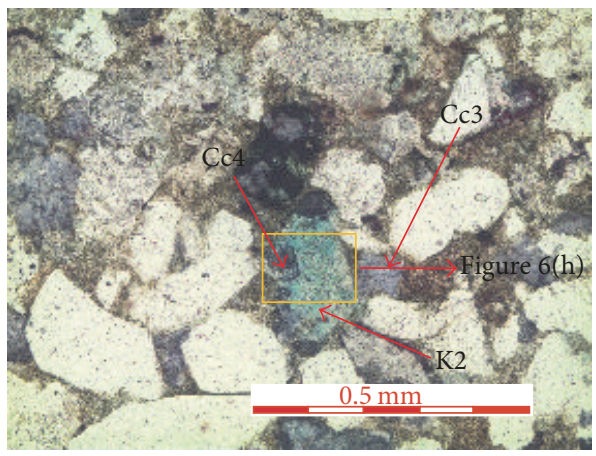

(g)

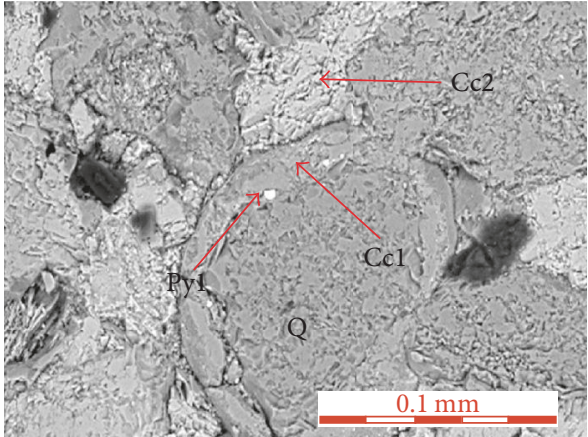

(b)

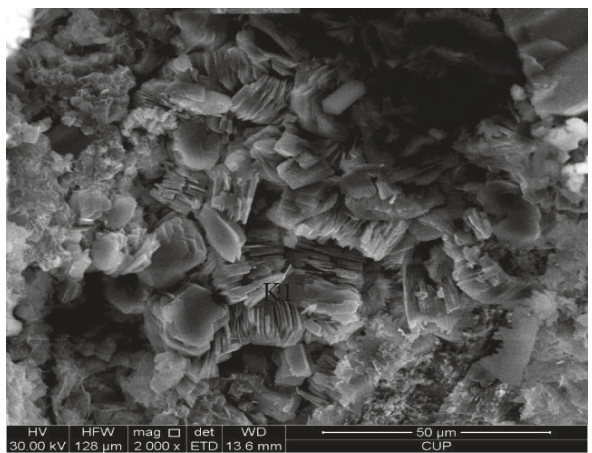

(d)

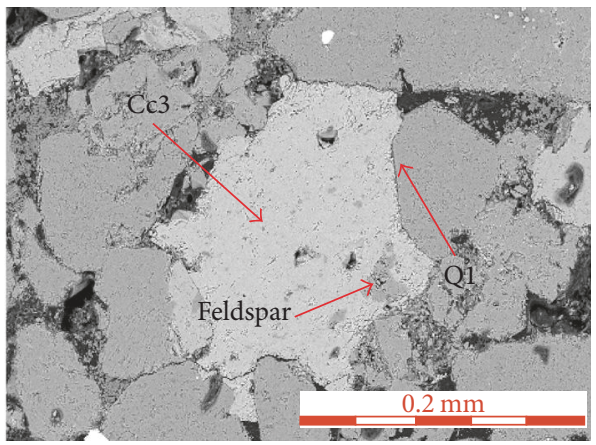

(f)

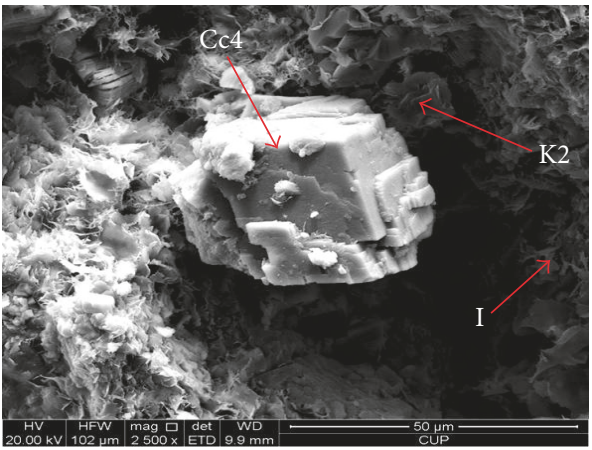

(h)

Figure 6: Morphological features of diagenetic products in Es of Dongying Sag. ((a) Well Shil27 $2180.8 \mathrm{~m}$, micritic high-Mg calcite (Cc1) and medium-coarse calcites (Cc2); (b) Well Shi127 2180.8 m, local amplification of (a), Cc1, Cc2, and Pyl; (c) Well Xin 1542960.50 m, Cc2 partly filled in primary pores and the outer part was filled by K1; (d) Well Xin 154, $2960.50 \mathrm{~m}$, local amplification of (c); (e) Well Niul10, 3004.80, dissolution of Cc3 and fillings in the outer of Q1; (g) Well FS1, 4322.40 m, Cc4 occurred in the outer of kaolinization feldspar (K2); (h) Well FS1, $4322.40 \mathrm{~m}$, local amplification of (g)). 


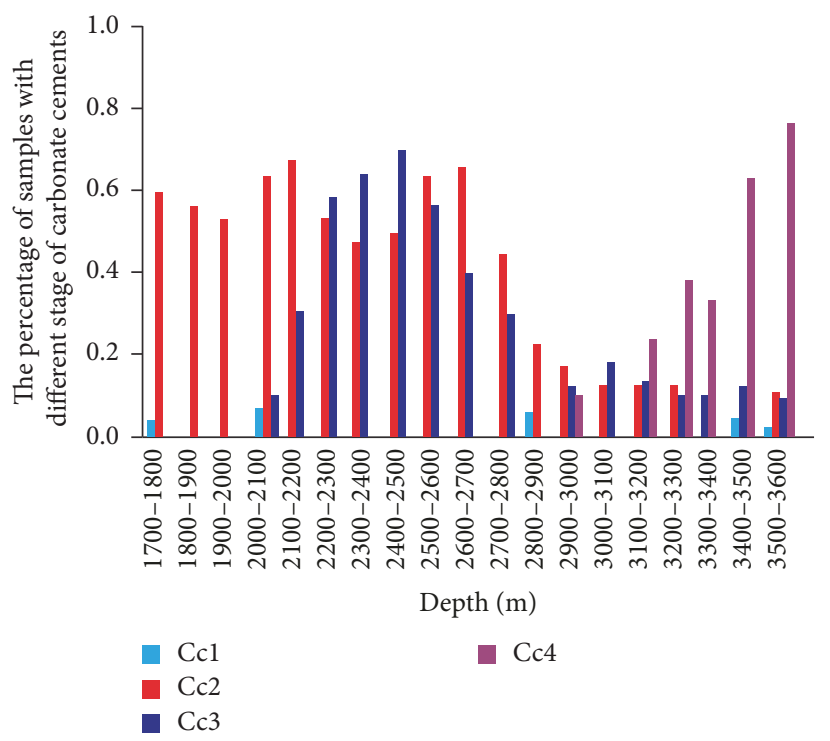

FIGURE 7: The distribution of carbonate cements with different morphological features in sandstone of Es in Dongying Sag.

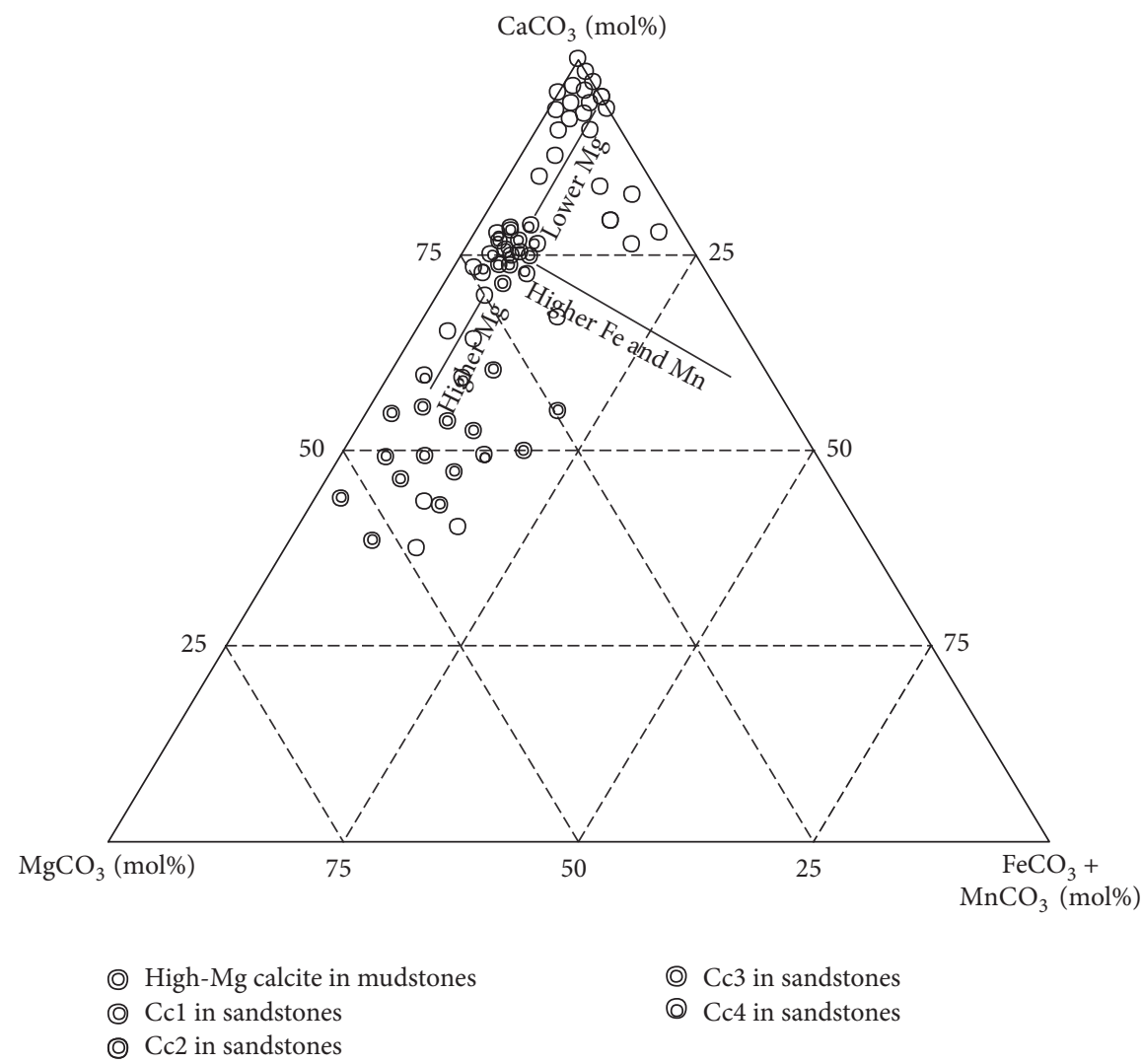

FIGURE 8: Geochemical characteristics of carbonate cements with different morphologies in Es of Dongying Sag.

mega- crystalline pore-filling quartz cements, and fracturefilling quartz cements (Figure 10). The first stage of quartz cements (Q1) was mainly in forms of quartz overgrowth, and the outer part was filled by Cc3 (Figures 6(e), and 6(f), 13(a), 13(b), and 13(c)). Q1 had a depth ranging from $2000 \mathrm{~m}$ to $3600 \mathrm{~m}$, mainly concentrated in $2500-3600 \mathrm{~m}$ (Figure 11). The second stage of authigenic quartz (Q2) was mainly euhedral quartz and fracture-filling quartz, filled in the outer 


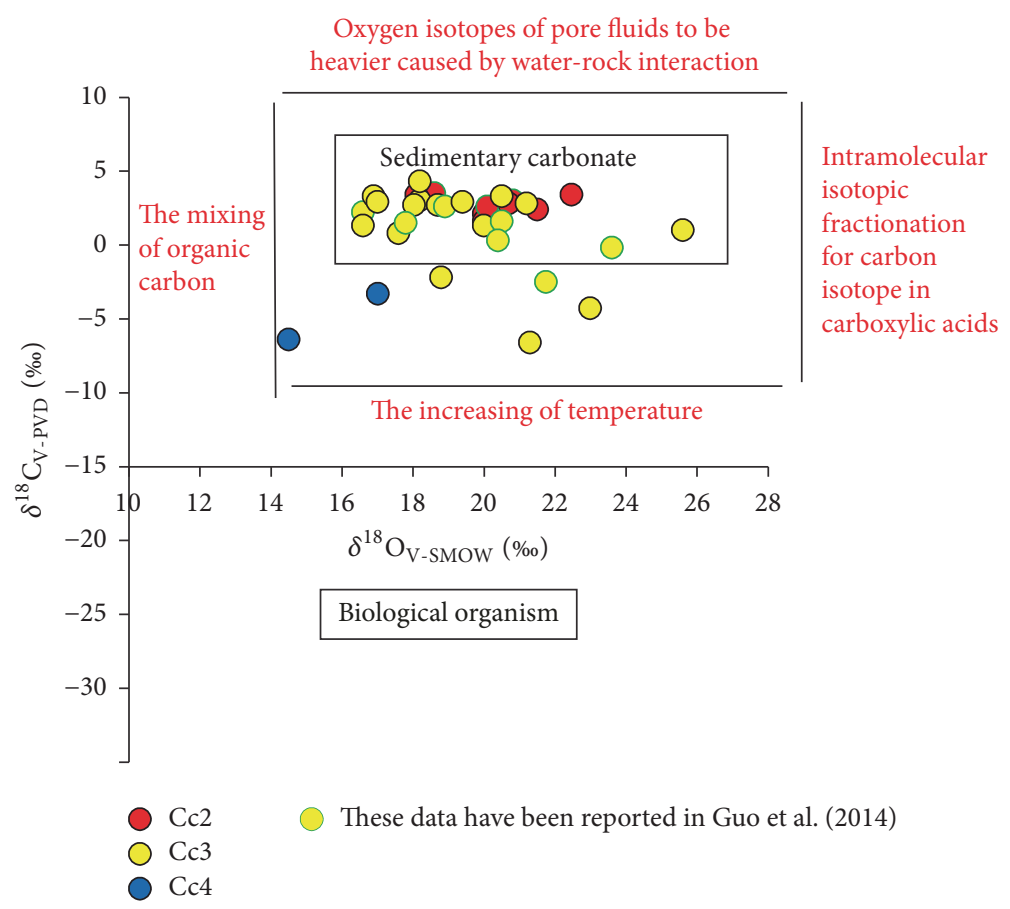

FIGURE 9: Isotope characteristics of carbonate cements with different morphologies in Es sandstones, Dongying Sag [37-46].

part or cutting Q1 (Figures 10(a) and 10(b)). Q2 was in a depth ranging from $2500 \mathrm{~m}$ to $3600 \mathrm{~m}$ and was mainly concentrated in $2900 \mathrm{~m}-3600 \mathrm{~m}$ (Figure 11).

The homogenization temperature of inclusions in Q1 ranged from $70^{\circ} \mathrm{C}$ to $115^{\circ} \mathrm{C}$ and that in $\mathrm{Q} 2$ from $110^{\circ} \mathrm{C}$ to $130^{\circ} \mathrm{C}$ (Figures 10(a), 10(b), and 12).

4.3.3. Distribution and Geochemical Features of Authigenic Kaolinites with Different Morphologies. The morphological features of authigenic kaolinites were comprehensively studied by thin section observation and SEM analysis. The authigenic kaolinites in the study area could be classified into two categories based on their morphologies. The first kind of authigenic kaolinite (K1) was featured by predominant scalyshape under the microscope (Figures 6(c), 13(a), and 13(c)) as well as single crystals characterized by closely packed, thin complete pseudohexagonal flakes under SEM. The wormlike or book-like aggregation of K1 (Figures 6(d), 13(b), and 13(d)) was mainly in feldspar dissolution pores and residual primary pores which had been partially filled by Cc2 (Figure 6(c)). K1 intergrew with quartz overgrowth (Q1) (Figure 13(b)), and it could be replaced by illites (Figure $13(\mathrm{~g})$ ). K1 had a wide range of distribution from $1700 \mathrm{~m}$ to $3600 \mathrm{~m}$ and was mainly concentrated in the range of $2600 \mathrm{~m}$ to $3200 \mathrm{~m}$ (Figure 14). Under microscopes, the second kind of authigenic kaolinite (K2) was mainly distributed on the surface of feldspar particles, showing disordered scales, and the aggregate of K2 presented in the shape of feldspar particles (Figures 6(g) and 13(e)). Under SEM, single crystals of K2 were flake-shaped, thin, and loosely arranged. These crystals had curved edges and imperfect forms (Figure 13(f)). K2 was mainly in dissolution pores within Cc3, with the outer side filled by Cc4 (Figures 6(g) and 6(h)). Part of K2 intergrew with authigenic quartz (Q2). K2 was mainly in the range of $2600 \mathrm{~m}$ to $3600 \mathrm{~m}$ and was mainly concentrated in the range of $2900-3200 \mathrm{~m}$ (Figure 14).

$\mathrm{K} 1$ mainly contained three elements, namely, $\mathrm{Al}, \mathrm{Si}$, and $\mathrm{O}$, while $\mathrm{K} 2$ had additional trace elements such as $\mathrm{K}$ (av. 1.01\%) and $\mathrm{Fe}$ (av. 1.89\%) (Table 2).

4.3.4. Morphological and Distribution Characteristics of Other Water-Rock Reaction Products. In the sandstones with depth less than $3200 \mathrm{~m}$, contents of illite (less than 5\%) and chlorite (less than $2 \%$ ) were relatively low and stable, while that of kaolinite increased significantly with depth (Figure 15). However, when the burial depth reached $3200 \mathrm{~m}$, the contents of illite and chlorite began to increase with depth, while that of kaolinites dropped (Figure 15), which was attributed to the transformation of kaolinites into illite and chlorite as observed under SEM (Figures 6(h), 13(g)).

There were mainly two kinds of authigenic pyrites in Es sandstones, Dongying Sag. The first kind of pyrites (Pyl) occurred as single particles in the inner side of $\mathrm{Ccl}$ (Figure 6(b)), while the other kind (Py2) occurred as framboids around Cc4 (Figure 13(h)).

\section{Discussion}

5.1. Formation Timing and Diagenetic Sequence of Major Diagenetic Products. The $\delta^{18} \mathrm{O}_{\text {smow }} / \%$ value of carbonate cements was controlled by formation temperatures and $\delta^{18} \mathrm{O}_{\text {smow }} / \%$ values of pore fluids. It was necessary to firstly determine $\delta^{18} \mathrm{O}_{\text {smow }} / \%$ values of pore when using $\delta^{18} \mathrm{O}_{\text {smow }} / \%$ o value of carbonate cements to calculate the formation 


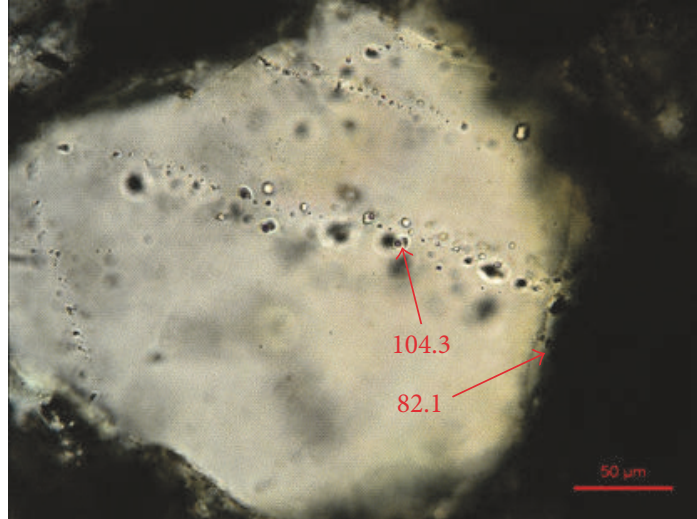

(a)

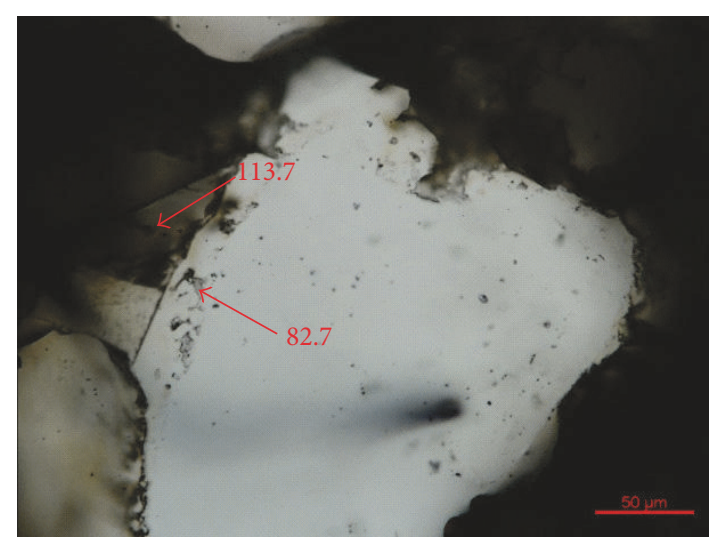

(b)

FIgURE 10: The inclusion characteristics of authigenic quartz in Dongying Sag. ((a) Well Y67, 2960.50 m; (b) Well S126, 3450.4 m).

TABLE 2: Element component characteristics of authigenic kaolinites in Es of Dongying Sag.

\begin{tabular}{|c|c|c|c|c|c|c|c|}
\hline \multirow{2}{*}{ Well ID } & \multirow{2}{*}{ Depth (m) } & \multirow{2}{*}{ Type } & \multicolumn{5}{|c|}{ Element content percentage (mol\%) } \\
\hline & & & $\mathrm{O}$ & $\mathrm{Al}$ & $\mathrm{Si}$ & $\mathrm{K}$ & $\mathrm{Fe}$ \\
\hline S 126 & 3386.40 & $\mathrm{~K} 1$ & 60.15 & 18.38 & 21.47 & - & - \\
\hline S 126 & 3386.40 & $\mathrm{~K} 1$ & 60.37 & 18.22 & 21.41 & - & - \\
\hline S 126 & 3428.60 & $\mathrm{~K} 1$ & 52.99 & 21.16 & 25.85 & - & - \\
\hline S 126 & 3428.60 & $\mathrm{~K} 1$ & 56.62 & 19.51 & 23.87 & - & - \\
\hline X 154 & 2935.90 & K1 & 58.34 & 18.87 & 22.79 & - & - \\
\hline N 105 & 3096.20 & $\mathrm{~K} 1$ & 56.61 & 20.24 & 23.15 & - & - \\
\hline Н 159 & 2960.30 & $\mathrm{~K} 1$ & 68.16 & 13.79 & 18.05 & - & - \\
\hline S 126 & 3513.1 & $\mathrm{~K} 1$ & 55.02 & 20.14 & 24.84 & - & - \\
\hline S 126 & 3450.40 & $\mathrm{~K} 1$ & 65.32 & 16.02 & 18.66 & - & - \\
\hline S 128 & 3452.40 & $\mathrm{~K} 1$ & 51.47 & 21.51 & 27.02 & - & - \\
\hline S 126 & 3450.40 & K2 & 48.13 & 19.94 & 27.70 & 2.23 & 2.00 \\
\hline S 126 & 3450.40 & $\mathrm{~K} 2$ & 50.80 & 19.61 & 28.28 & 0.52 & 0.78 \\
\hline S 126 & 3450.40 & $\mathrm{~K} 2$ & 50.55 & 13.47 & 31.95 & 1.20 & 2.84 \\
\hline N 105 & 3096.20 & K2 & 56.90 & 15.58 & 25.13 & 0.76 & 1.63 \\
\hline N 105 & 3096.20 & K2 & 51.08 & 20.97 & 27.19 & 0.76 & - \\
\hline N 105 & 3096.20 & $\mathrm{~K} 2$ & 49.41 & 22.03 & 28.07 & 0.49 & - \\
\hline S 126 & 3513.1 & $\mathrm{~K} 2$ & 55.00 & 20.44 & 23.02 & 0.68 & 0.86 \\
\hline S 126 & 3513.1 & $\mathrm{~K} 2$ & 53.64 & 18.30 & 25.27 & 1.63 & 1.16 \\
\hline S 127 & 3451.40 & K2 & 48.95 & 20.63 & 28.01 & 0.95 & 1.46 \\
\hline S 130 & 3454.40 & K2 & 47.52 & 21.64 & 27.50 & - & 3.34 \\
\hline S 131 & 3455.40 & $\mathrm{~K} 2$ & 52.62 & 18.50 & 25.05 & 0.87 & 2.96 \\
\hline
\end{tabular}

temperature [37, 48]. During diagenetic process, material exchanges between particles and pore fluids (mainly feldspar dissolution) led the $\delta^{18} \mathrm{O}_{\text {smow }} / \%$ value of pore fluids to be heavier $[35,39,43]$. The $\delta^{18} \mathrm{O}_{\text {smow }} / \%$ value of pore water at eodiagenetic stage was about $-4.8 \%$, which became heavier, reaching about $-3 \%$ due to significant feldspar dissolution $[35,49]$. In other words, $\mathrm{Ccl}$ and $\mathrm{Cc} 2$, which were clearly anterior to feldspar dissolution, precipitated from pore fluids with $\delta^{18} \mathrm{O}_{\text {smow }} / \%$ value of $-4.8 \%$ (Figures $6(\mathrm{a}), 6(\mathrm{~b})$, and 6(c)), while $\mathrm{Cc} 3$ and $\mathrm{Cc} 4$, which were clearly posterior to feldspar dissolution, precipitated from pore fluids with $\delta^{1} \mathrm{O}_{\text {smow }} / \%$ value of $-3 \%$ (Figures $6(\mathrm{e}), 6(\mathrm{f}), 6(\mathrm{~g})$, and $6(\mathrm{~h})$ ). The chemical composition of $\mathrm{Ccl}$ was similar to micritic high-Mg calcite formed during syndiagenetic stage in shales (Figure 8). Thus, it could be deduced that $\mathrm{Ccl}$ should be formed during syndiagenetic stage as well. The $\delta^{18} \mathrm{O}_{\mathrm{V}-\mathrm{PDB}} / \%$ o values of $\mathrm{Cc} 2$ ranged from $-12.40 \%$ o to $-8.20 \%$, indicating the formation temperature range of $\mathrm{Cc} 2$ to be $33.2-58.1^{\circ} \mathrm{C}$. The $\delta^{18} \mathrm{O}_{\mathrm{V}-\mathrm{PDB}} / \%$ value of $\mathrm{Cc} 3$ ranged from $-13.90 \%$ o to $-5.10 \%$, suggesting the formation temperature range of $\mathrm{Cc} 3$ 


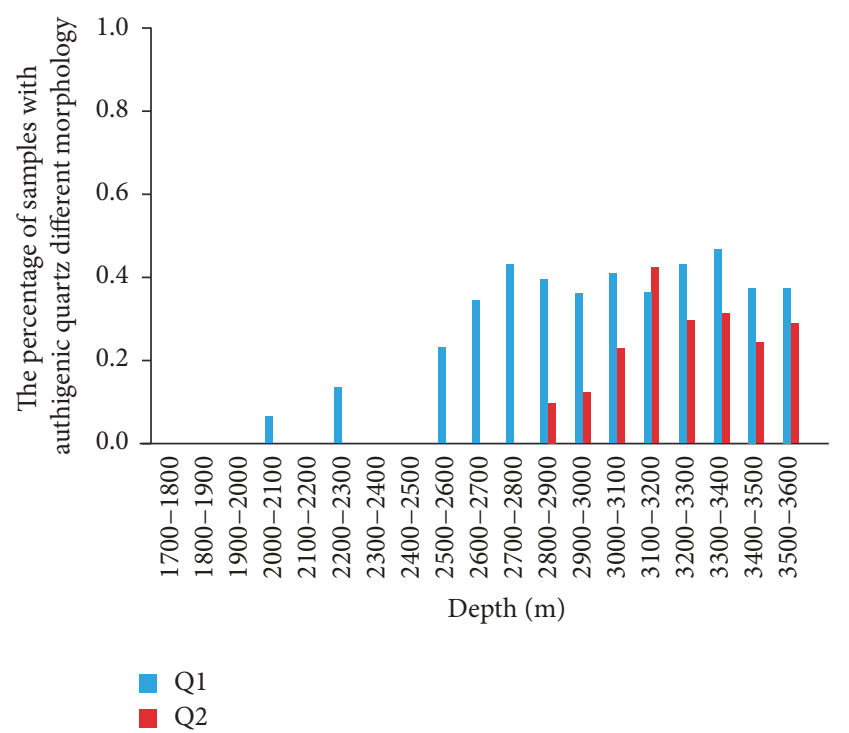

FIGURE 11: The distribution of authigenic quartz with different morphological features in sandstone of Es in Dongying Sag.

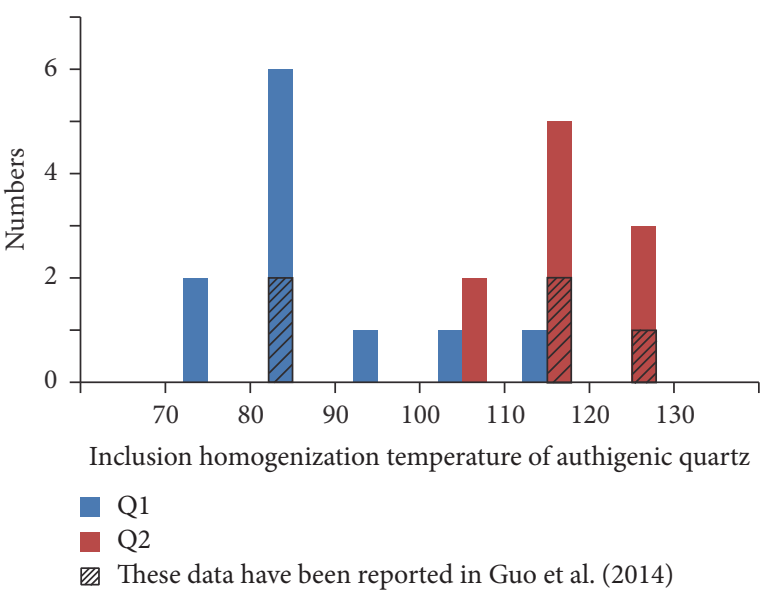

FIGURE 12: The homogenization temperature of inclusion of authigenic quartz with different morphological features in sandstones of Es, Dongying Sag.

to be $50.0-115.2^{\circ} \mathrm{C}$. Similarly, the $\delta^{18} \mathrm{O}_{\mathrm{V}-\mathrm{PDB}} / \%$ of Cc4 ranged from $-15.90 \%$ to $-13.50 \%$, implying the formation temperature range of $\mathrm{Cc} 3$ to be $130-170^{\circ} \mathrm{C}[37,48]$.

The homogenization temperatures of brine inclusions in $\mathrm{Q} 1$ and Q2, respectively, ranged from $70^{\circ} \mathrm{C}$ to $115^{\circ} \mathrm{C}$ and from $110^{\circ} \mathrm{C}$ to $130^{\circ} \mathrm{C}$ (Figures $10(\mathrm{a}), 10(\mathrm{~b})$, and 12 ).

$\mathrm{K} 1$, which was posterior to cementation of $\mathrm{Cc1}$ and $\mathrm{Cc} 2$ and prior to $\mathrm{Cc} 3$, generally presented as intergrowth of $\mathrm{Q} 1$ (Figures 6(c), 6(h), and 13(b)), indicating the formation temperature range of $\mathrm{K} 1$ to be $70-115^{\circ} \mathrm{C}$. $\mathrm{K} 2$, which was posterior to cementation of $\mathrm{Cc} 3$ and anterior to $\mathrm{Cc} 4$, generally occurred as intergrowth of $\mathrm{K} 2$, implying the formation temperature of $\mathrm{K} 1$ to range from $115^{\circ} \mathrm{C}$ to $130^{\circ} \mathrm{C}$.

Chlorite and illite were synchronous with or posterior to $\mathrm{Cc} 4$ and were concentrated in depth more than $3200 \mathrm{~m}$ $\left(>140^{\circ} \mathrm{C}\right)$, suggesting that they were the latest diagenetic products (Figure 6(h), and 15).

Pyl was generally associated with Ccl (Figure 6(b)) and Py2 with Cc4 (Figure 13(h)).

Finally, the diagenetic sequence of sandstones in Es, Dongying Sag, was concluded as shown in Figure 16.

\subsection{Material Sources of Main Diagenetic Products}

5.2.1. Material Sources of Carbonate Cements. Ccl could be directly precipitated out from sedimentary waters during syndiagenetic stage [51]. The $\delta^{13} \mathrm{C}_{\mathrm{PDB}} / \%$ and $\delta^{18} \mathrm{O}_{\mathrm{PDB}} / \%$ o values of $\mathrm{Cc} 2$ in sandstones ranged from $1.60 \%$ to $3.50 \%$ and from $-12.4 \%$ to $-8.2 \%$, respectively, indicating Cc2 to be typical lacustrine carbonate cements (Figure 9). Cc2 mainly occurred in sandstones which were proximal to sand-shale interfaces [52-55]. Formation temperatures of Cc2 were within the range of $33.2-58.1^{\circ} \mathrm{C}$, which corresponded to the depth range of 500-1000 $\mathrm{m}$ [50]. In this depth range, the porosity of mudstones declined from $60 \%$ to $10-20 \%$ because of compaction, leading to discharge of a large amount of sedimentary water into sandstones $[13,53,55-58] . \mathrm{Ca}^{2+}$ and $\mathrm{CO}_{3}{ }^{2-}$ were rich in those fluids, and they were main material sources for Cc2.

The $\delta^{13} \mathrm{C}_{\mathrm{PDB}} / \%$ and $\delta^{18} \mathrm{O}_{\mathrm{PDB}} / \%$ values of $\mathrm{Cc} 3$ in sandstones mainly ranged from $-6.6 \%$ to $4.3 \%$ and from $-13.9 \%$ o to $-5.1 \%$, respectively, which indicated the influence of organic carbon on part of Cc3 (Figure 9). The chemical composition of Cc3 was complex (Figure 8). Vertically, Cc3 was mainly concentrated in transitional areas of normalpressure and overpressure zones (Figure 7; [59]). Laterally, distribution of Cc3 was controlled by main faults [59]. All of these proved that hydrothermal fluids that flowed through the faults provided part of the material sources for $\mathrm{Cc} 3$. Formation temperatures of $\mathrm{Cc} 3$ ranged from $50.0^{\circ} \mathrm{C}$ to $115.2^{\circ} \mathrm{C}$, in the range of which carboxylic acids were formed and expelled from organic matters into mudstones $[13,60]$. The presence of carboxylic acids led to dissolution of plagioclases (mainly Ca-feldspars and Na-feldspars) and also caused the entrance of $\mathrm{Ca}^{2+}$ and $\mathrm{Na}^{+}$into pore fluids (Figures 4, 6(f), and 5). During this time, no obvious dissolution of $\mathrm{Cc1}$ and $\mathrm{Cc} 2$ occurred (Figure 6(c), Figure 7; [61]). The $\mathrm{Ca}^{2+}, \mathrm{Mg}^{2+}$, and $\mathrm{CO}_{3}{ }^{2-}$ (partly influenced by organic carbon) in hydrothermal fluids and $\mathrm{Ca}^{2+}$ (dissolved by Ca-feldspar) and $\mathrm{CO}_{3}{ }^{2-}$ (sedimentary carbon) in formation water were material sources for $\mathrm{Cc} 3[59,62,63]$.

The $\delta^{13} \mathrm{C}_{\mathrm{PDB}} / \%$ and $\delta^{18} \mathrm{O}_{\mathrm{PDB}} / \%$ values of $\mathrm{Cc} 4$ in sandstones ranged from $-6.4 \%$ to $-3.3 \%$ and from $-15.9 \%$ to $-13.5 \%$, respectively, indicating the significant influence of organic carbon on Cc4 (Figure 9). Cc4 was mainly concentrated in sandstones with depth over $3200 \mathrm{~m}$ (Figure 7). At this depth (corresponding temperature $>120^{\circ} \mathrm{C}$ ), cracking of carboxylic acids and organic matters resulted in a large amount of $\mathrm{CO}_{2}$, which was transformed to $\mathrm{CO}_{3}{ }^{2-}$ in the following diagenetic processes $[13,27,35,50,54,60]$. Carbonate cements (mainly $\mathrm{Cc} 2$ and $\mathrm{Cc} 3$ ) were dissolved obviously, leading to the entrance of $\mathrm{Ca}^{2+}$ and $\mathrm{CO}_{3}{ }^{2-}$ into pore fluids (Figures 6(e), and 7; [64]). The dissolution of metamorphic 


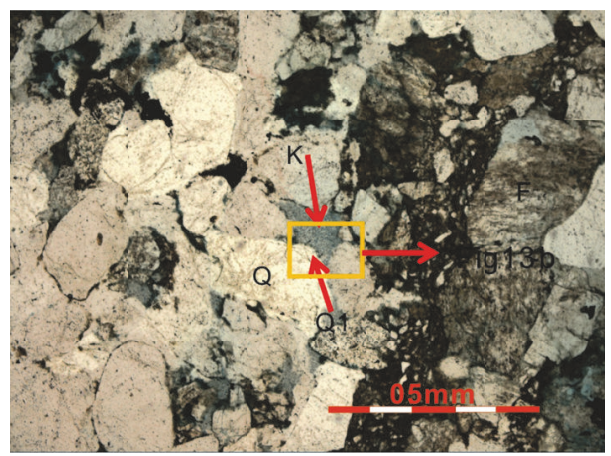

(a)

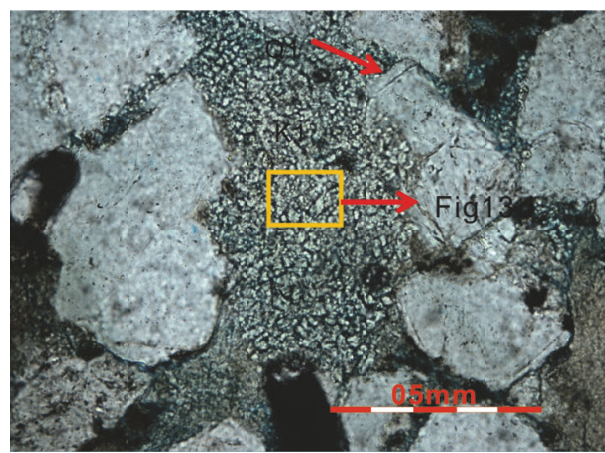

(c)

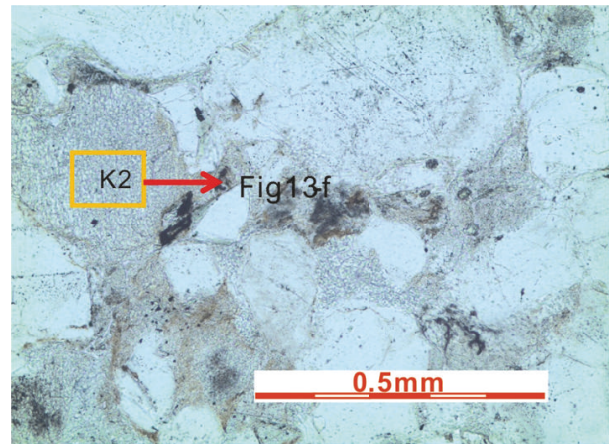

(e)

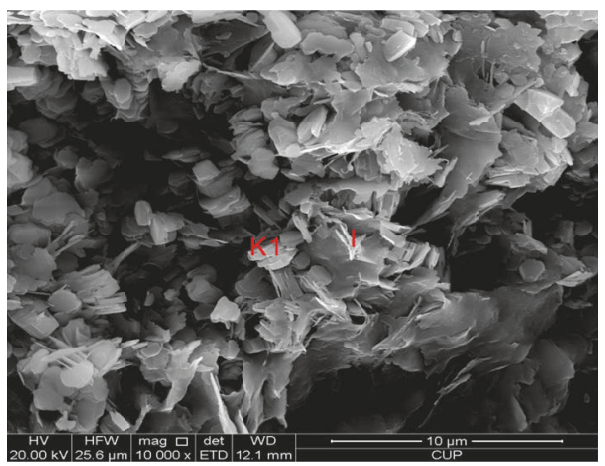

(g)

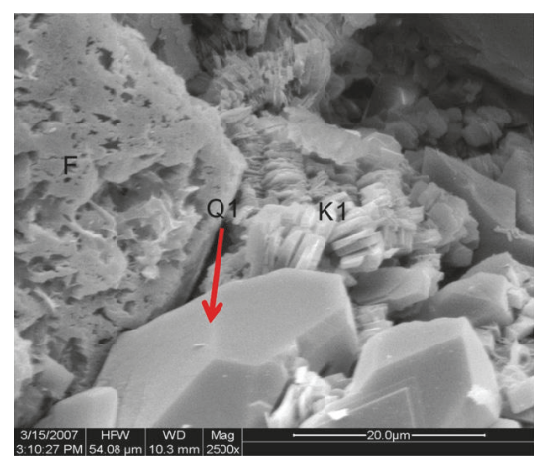

(b)

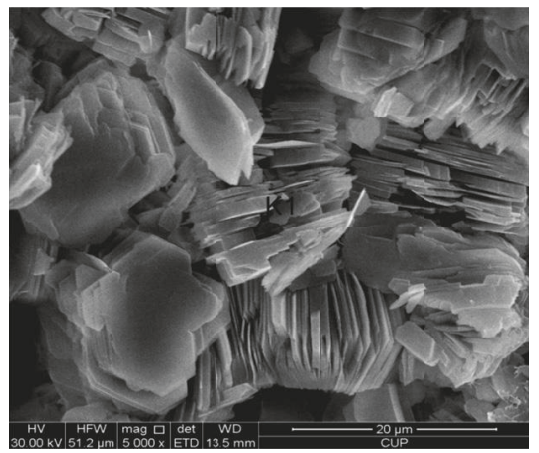

(d)

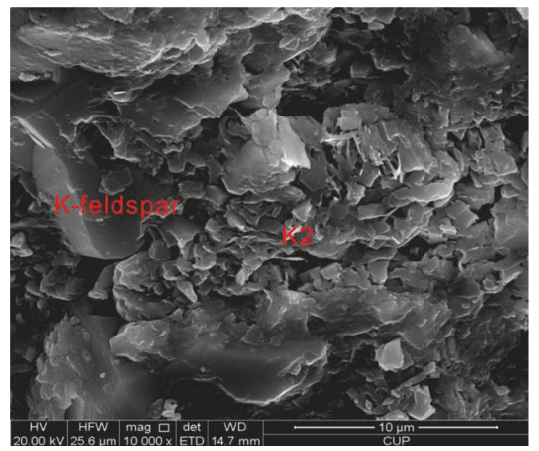

(f)

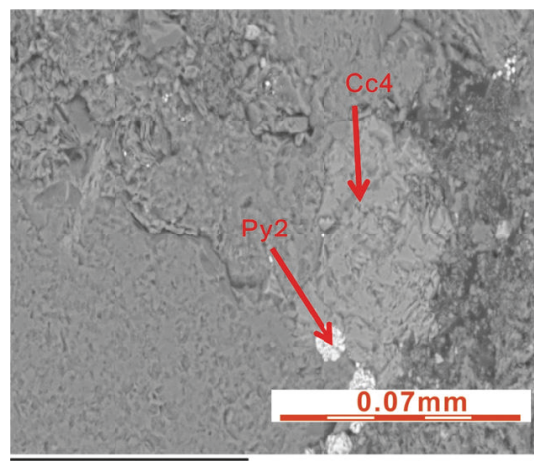

(h)

FIGURE 13: Morphological features of diagenetic products in Es of Dongying Sag. ((a) Well He 142, 3064.83 m, wormlike authigenic kaolinites (K1) intergrew with quartz overgrowths; (b) Well He 142, $3064.83 \mathrm{~m}$, local amplification of (a), K1 intergrew with quartz overgrowths; (c) Well Xin 154, 2938.56 m, K1 filled in secondary pores; (d) Well Xin 154, 2938.56 m, local amplification of (c), wormlike authigenic kaolinite (K1); (e) Well N105, 3096.2 m, disordered authigenic kaolinite distributed on the surface of K-feldspars (K2); (f) Well N105, 3096.2 m, local amplification of (e); (g) Well XX161, 3272.5 m, illitization of K1 and K2; (h) Well S106, 3398.70 m, Cc4 and Py2). 


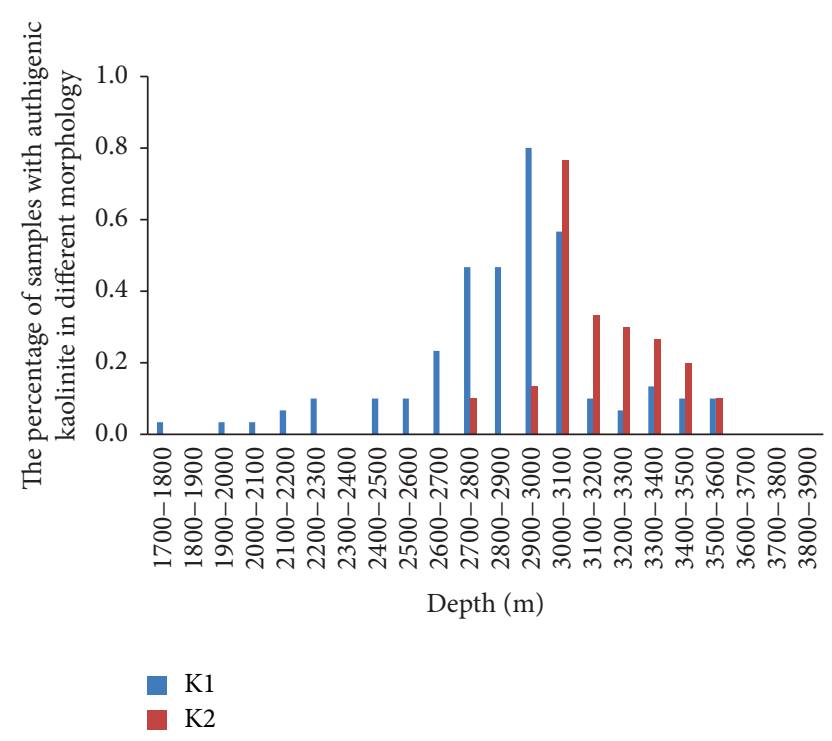

Figure 14: The distribution of authigenic kaolinites with different morphologies in Es sandstone of Dongying Sag [47].

lithic fragments promoted the entrance of $\mathrm{Fe}^{2+}$ and $\mathrm{Mg}^{2+}$ into pore fluids (Figure 4). All of these materials were the sources for precipitation of Cc4.

5.2.2. Material Sources of Authigenic Quartz. Precipitation of authigenic quartz occurred in the diagenesis process (Figure 16) as the concentration of $\mathrm{SiO}_{2}(\mathrm{aq})(<100 \mathrm{ppm})$ in lake waters was too low for authigenic quartz [11]. There were no external sources of free $\mathrm{SiO}_{2}$ for sandstones of Es in Dongying Sag [35]. However, quartz dissolution at grain contacts and dissolution or transformation of feldspars in sandstones could be possible internal source for authigenic quartz. Contact relationships of Es sandstones were mainly point contact, with a small proportion of line contact (Figures 6(a), 6(c), 13(a), and 13(c)). No much free $\mathrm{SiO}_{2}$ (aq) was released during this process. Therefore, the depth distribution range of authigenic quartz was identical to that of feldspar (Figures 4 and 11). In the thin sections and SEM, dissolution and transformation of feldspars associated with authigenic quartz could be identified (Figure 13(b)). Therefore, the most likely source of authigenic quartz might be the internal dissolution and transformation of feldspars.

5.2.3. Material Sources of Authigenic Kaolinites. The concentrations of $\mathrm{SiO}_{2}$ (aq) $(<100 \mathrm{ppm})$ and $\mathrm{Al}^{3+}(<10 \mathrm{ppm})$ were too low to be effective material source for authigenic kaolinites [11]. However, there were a lot of authigenic kaolinites in the sandstone reservoirs of Es in Dongying Sag. Vertically, the content of authigenic kaolinites was negatively correlated with feldspar content (Figures 4 and 14; [35, 47, 65]). In other words, the dissolution of aluminosilicate minerals (mainly feldspars) was important material source for authigenic kaolinites [9, 66-71].

$\mathrm{K} 1$ was featured by perfect crystal forms and exclusive $\mathrm{Al}$, $\mathrm{Si}$, and $\mathrm{O}$ ions, indicating those authigenic kaolinites to be precipitated directly from pore fluids [72,73]. High content of K1 often appeared in samples with no or little feldspar dissolution, while low content of $\mathrm{K} 1$ was common in samples with a large amount of feldspar dissolution [74], which indicated the significant amount of free $\mathrm{Si}^{4+}$ and $\mathrm{Al}^{3+}$ which are released by dissolution of feldspar and then migration in pore fluids during the formation of K1. In the deep burial environment, pore fluids flowed slowly, dissolving only a small amount of free $\mathrm{Si}^{4+}$ and $\mathrm{Al}^{3+}$. Therefore, it was hard for silicon and aluminum to migrate in the form of $\mathrm{Si}^{4+}$ and $\mathrm{Al}^{3+}$ [75-77]. Considering the formation temperature $\left(60-115^{\circ} \mathrm{C}\right)$ of $\mathrm{K} 1$, which was suitable for formation and preservation of carboxylic acids, it was suggested that complex reaction between carboxylic acids and cations of $\mathrm{Si}^{4+}$ and $\mathrm{Al}^{3+}$ could induce the dissolution of feldspars $[27,35,78]$. The $\mathrm{Si}^{4+}$ and $\mathrm{Al}^{3+}$ migrated over long distances in the form of clathrates and precipitated as authigenic kaolinite (K1) in the proper geological environment.

K2 was featured by imperfect crystal forms and more other ions (like $\mathrm{Fe}$ and $\mathrm{K}$ ) besides $\mathrm{Al}, \mathrm{Si}$, and $\mathrm{O}$, which indicated these authigenic kaolinites to be products of feldspar transformation $[72,73]$. Pore fluids rich in $\mathrm{CO}_{2}$ led to the occurrence of a large amount of $\mathrm{H}^{+}$and $\mathrm{HCO}_{3}{ }^{-}$in pore fluids at the depth of 2800-3200 m (Figure 5). Under this situation, $\mathrm{K}$-feldspar particles were totally or partly transformed into K2 and Q2 [5, 61].

5.2.4. Material Sources of Other Water-Rock Reaction Products. In the depth range of 2800-3200 m, kaolinization of Kfeldspars and dissolution of metamorphic lithic fragments led to concentration of $\mathrm{K}^{+}, \mathrm{Fe}^{2+}$, and $\mathrm{Mg}^{2+}$ in pore fluids. At the same time, a large amount of $\mathrm{H}^{+}$was consumed. All of these led authigenic kaolinites ( $\mathrm{K} 1$ and $\mathrm{K} 2$ ) to be unstable [56, 79]. Once the depth was above $3200 \mathrm{~m}\left(130^{\circ} \mathrm{C}\right), \mathrm{K} 1$ and $\mathrm{K} 2$ were partly or totally transformed into illites and chlorites (Figures 6(h), 13(g), and 15).

\subsection{Material Exchanges between Pore Fluids and Rocks during} Diagenetic Processes. The material exchange between pore fluids and rocks was mainly controlled by geochemical and physical properties of pore fluids. During diagenetic processes, fluids, which were recharged by mudstones and flowed along faults, could lead to obvious changes of properties of pore fluids. Based on analyses of changes of detrital composition, geochemical features of pore fluids, and material sources of diagenetic products in Es of Dongying Sag, this study divided the material exchanges during diagenetic processes in rift basins into five stages.

Stage 1. Certain amounts of $\mathrm{Ca}^{2+}, \mathrm{Mg}^{2+}, \mathrm{Fe}^{3+}, \mathrm{CO}_{3}{ }^{2-}$, and $\mathrm{SO}_{4}{ }^{2-}$ were existent in lake waters of the Paleogene in Dongying Sag [51, 80, 81]. During syngenetic stage, evaporation of lake water led to concentration of ions, and they precipitated as a small amount of micritic high-Mg calcite [51, 54, 81-83]. At the same time, activities of sulfate-reducing bacteria led to the change of $\mathrm{Fe}^{3+}$ and $\mathrm{SO}_{4}{ }^{2-}$ to $\mathrm{Fe}^{2+}$ and $\mathrm{S}^{2-}$, respectively. Part of $\mathrm{Fe}^{2+}$ entered into crystal lattices of $\mathrm{Ccl}$ as 

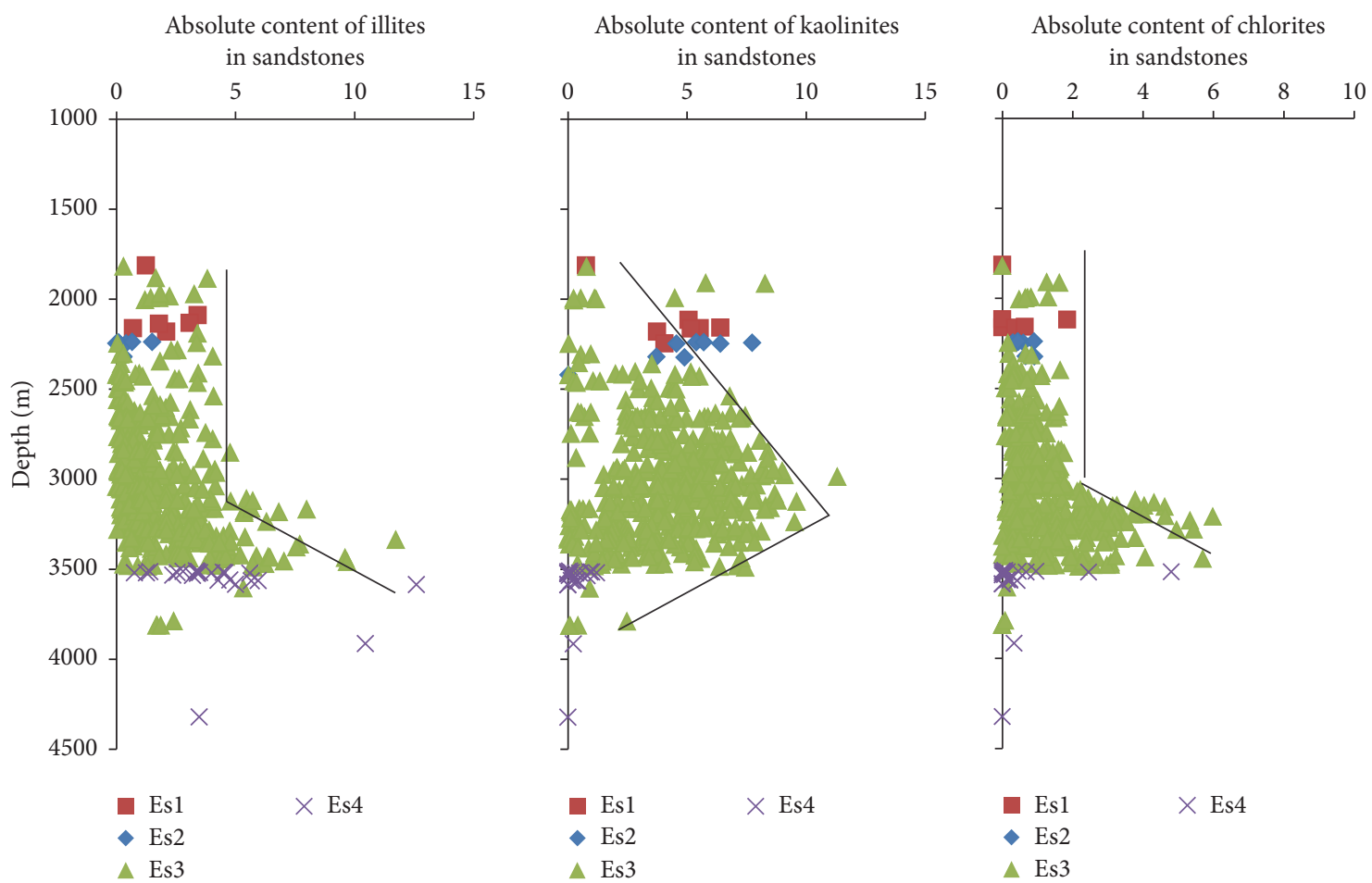

FIGURE 15: The content changes of clay minerals in Es sandstones from Dongying Sag.

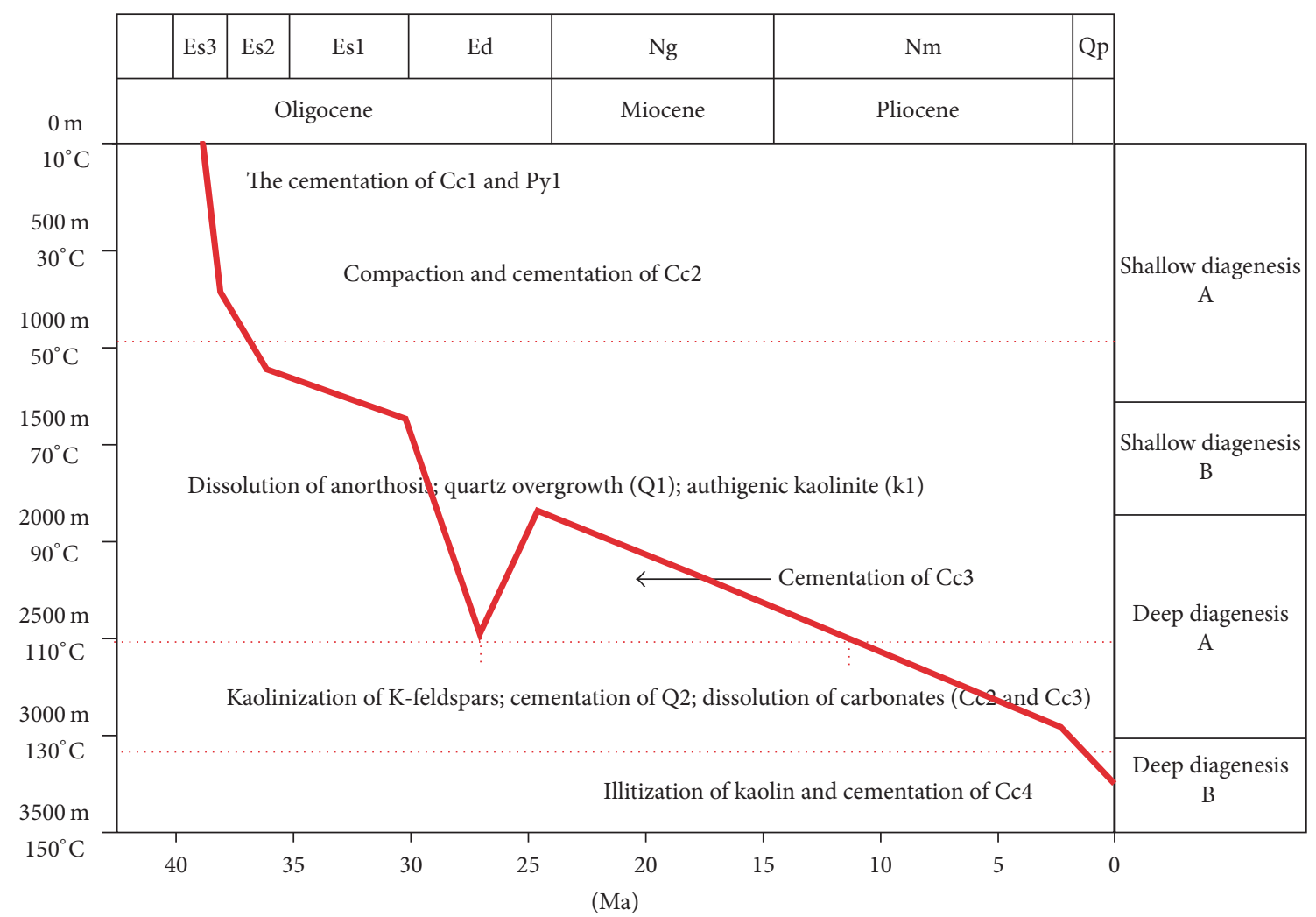

FIGURE 16: The diagenetic sequence of Es in Dongying Sag (paleogeothermal data was based on [50]; burial history was based on [47]). 
heteroatom, while the remaining part was combined with $\mathrm{S}^{2-}$, precipitating as $\mathrm{Pyl}$ associated with $\mathrm{Ccl}$. In this stage, mainly $\mathrm{Mg}^{2+}, \mathrm{Ca}^{2+}, \mathrm{CO}_{3}{ }^{2-}, \mathrm{Fe}^{2+}$, and $\mathrm{SO}_{4}{ }^{2-}$, which originated from lake waters, entered sandstones in the forms of Ccl and Pyl.

Stage 2. In the depth range of 500-1000 m (paleotemperature of $30-50^{\circ} \mathrm{C}$ ), concentrated compaction waters rich in $\mathrm{Ca}^{2+}$ and $\mathrm{CO}_{3}{ }^{2-}$ entered into sandstones from mudstones, resulting in the formation of $\mathrm{Cc} 2$ in sandstones close to the sandstone-mudstone interfaces. During this stage, $\mathrm{Ca}^{2+}$ and $\mathrm{CO}_{3}{ }^{2-}$ from compaction waters entered into sandstones and precipitated as $\mathrm{Cc} 2$.

Stage 3. In the depth range of $1250-2800 \mathrm{~m}$ (paleotemperature of $60-120^{\circ} \mathrm{C}$ ), waters rich in carboxylic acids enter into sandstones from mudstones, leading to dissolution of plagioclases. In this process, $\mathrm{Na}^{+}$and $\mathrm{Ca}^{2+}$ entered into pore fluids and were well preserved. $\mathrm{Si}^{4+}$ and $\mathrm{Al}^{3+}$ were complexed with carboxylic acids, and these complexes migrated in pores and then precipitated as K1 and Q1 in the proper geological conditions. In this stage, activation of faults could cause the blend of hydrothermal fluids (upwelling through faults, rich in $\mathrm{Mg}^{2+}, \mathrm{Ca}^{2+}$, and partly organic source $\mathrm{CO}_{3}{ }^{2-}$ ) and formation waters (in place, rich in $\mathrm{Ca}^{2+}$ ), leading to the precipitation of $\mathrm{Cc} 3$.

Stage 4. In the depth range of $2800-3200 \mathrm{~m}$ (paleotemperature of $120-140^{\circ} \mathrm{C}$ ), $\mathrm{CO}_{2}$ with organic sources, formed by cracking of organic matters and carboxylic acids, entered the pore fluids and was preserved as $\mathrm{H}_{2} \mathrm{CO}_{3}\left(\mathrm{HCO}_{3}{ }^{-}\right)$. The presence of organic source $\mathrm{H}_{2} \mathrm{CO}_{3}\left(\mathrm{HCO}_{3}^{-}\right)$led to the transformation of $\mathrm{K}$-feldspars and the dissolution of $\mathrm{Cc} 2, \mathrm{Cc} 3$, and metamorphic lithic fragments. During transformation of Kfeldspars, a large amount of $\mathrm{K}^{+}$entered into pore fluids and was well preserved. The dissolution of $\mathrm{Cc} 2$ and $\mathrm{Cc} 3$ led to the entrance of a large amount of sedimentary source $\mathrm{Ca}^{2+}$ and $\mathrm{CO}_{3}{ }^{2-}$ into pore fluids, which were then well preserved. The dissolution and transformation of metamorphic lithic fragments led to the entrance of $\mathrm{Fe}^{2+}$ and $\mathrm{Mg}^{2+}$ into pore fluids and subsequently good preservation (Figure 5). The transformation of $\mathrm{K}$-feldspars led to the formation of $\mathrm{K} 2$ and Q2. In this process, $\mathrm{K}^{+}, \mathrm{Ca}^{2+}, \mathrm{CO}_{3}{ }^{2-}, \mathrm{Mg}^{2+}, \mathrm{Fe}^{2+}$, and $\mathrm{Mn}^{2+}$ entered pore fluids.

Stage 5. In the depth above $3200 \mathrm{~m}$ (paleotemperature above $140^{\circ} \mathrm{C}$ ), less or no formation of organic $\mathrm{CO}_{2}$ resulted in the transformation of pore fluids into alkaline. In this depth range, the contents of $\mathrm{Na}^{+}, \mathrm{K}^{+}, \mathrm{Ca}^{2+}$, and $\mathrm{HCO}_{3}{ }^{-}$significantly declined (Figure 5), which might be due to the precipitation of $\mathrm{Cc} 4$ as well as illitization and chloritization of $\mathrm{K}$. During this process, because of declining of $\mathrm{H}^{+}, \mathrm{HCO}_{3}{ }^{2-}$ transformed to $\mathrm{CO}_{3}{ }^{2-}$. This caused $\mathrm{CO}_{3}{ }^{2-}$ (dissolution of $\mathrm{Cc} 2$ and $\mathrm{Cc} 3$, organic source $\left.\mathrm{CO}_{3}{ }^{2-}\right), \mathrm{Ca}^{2+}, \mathrm{Mg}^{2+}, \mathrm{Fe}^{2+}$, and $\mathrm{Mn}^{2+}$ to precipitate as $\mathrm{Cc} 4$. Concentration of $\mathrm{K}^{+}$and declining of $\mathrm{H}^{+}$contributed to the transformation of $\mathrm{K} 1$ and $\mathrm{K} 2$ into illites, while concentration of $\mathrm{Mg}^{2+}$ and $\mathrm{Fe}^{2+}$ as well as declining of $\mathrm{H}^{+}$led to the transformation of $\mathrm{K} 1$ and $\mathrm{K} 2$ into chlorites. In this process, $\mathrm{CO}_{3}{ }^{2-}, \mathrm{Ca}^{2+}, \mathrm{Mg}^{2+}, \mathrm{Fe}^{2+}, \mathrm{Mn}^{2+}$, and $\mathrm{K}^{+}$entered sandstones in the forms of $\mathrm{Cc} 4$, illites, and chlorites.

\section{Conclusions}

The material exchange of pore fluids in rift basins could be divided into five stages. The first stage was the near surface evaporation concentration stage, during which $\mathrm{Ca}^{2+}, \mathrm{Mg}^{2+}$, and $\mathrm{CO}_{3}{ }^{2-}$ in lake waters precipitated as high-Mg calcites (Ccl), mainly caused by evaporation. The second stage was the shale compaction stage, during which $\mathrm{Ca}^{2+}$ and $\mathrm{CO}_{3}{ }^{2-}$ from shale compaction waters precipitated as calcites (Cc2), mainly caused by compaction of shales. The third stage was the carboxylic acid dissolution stage, during which dissolution of plagioclases (by carboxylic acid) occurred. During this stage, $\mathrm{Ca}^{2+}$ and $\mathrm{Na}^{+}$entered into pore fluids as ions, while $\mathrm{Si}^{4+}$ and $\mathrm{Al}^{3+}$ entered into pore fluids and migrated as clathrates, ultimately precipitating as kaolinites (K1) and quartz overgrowth (Q1). Partly, the upwelling of hydrothermal fluids caused by active faults led to the precipitation of carbon cements (Cc3). Those processes were mainly caused by carboxylic acids and upwelling of hydrothermal fluids. The fourth stage was the organic $\mathrm{CO}_{2}$ stage, which was featured by the kaolinization of K-feldspar, formation of organic $\mathrm{CO}_{2}$, and dissolution of metamorphic lithic fragments and carbon cements (mainly Cc2 and Cc3). During this stage, $\mathrm{K}^{+}, \mathrm{Fe}^{2+}$, $\mathrm{Mg}^{2+}, \mathrm{Ca}^{2+}, \mathrm{HCO}_{3}{ }^{-}$, and $\mathrm{CO}_{3}{ }^{2-}$ entered into pore fluids, driven by formation of organic $\mathrm{CO}_{2}$. The fifth stage was the alkaline fluid stage, which was characterized by the cementation of ferro-carbonates and ankerite as well as illitization or chloritization of kaolinites. During this stage, $\mathrm{K}^{+}, \mathrm{Fe}^{2+}, \mathrm{Mg}^{2+}$, $\mathrm{Ca}^{2+}$, and $\mathrm{CO}_{3}{ }^{2-}$ precipitated from pore fluids and entered into sandstones, caused by declining concentration of $\mathrm{H}^{+}$.

\section{Conflicts of Interest}

The authors declare that they have no conflicts of interest.

\section{Acknowledgments}

This study was financially supported by the National Science and Technology Special Grant (no. 2016ZX05006001) and National Natural Science Foundation of China (no. 41172128). The authors also appreciate Shengli Oilfield Company of Sinopec for providing core samples and other geological data of Dongying Sag.

\section{References}

[1] M. C. Li, J. Li, Y. J. Wan, Z. Y. Deng, and X. Q. Du, "Fluids in the sedimentary basin," Acta Petrolei Sinica, vol. 04, pp. 13-17, 2001, [In Chinese with English abstract].

[2] J. H. Zeng, "Geofluids Flow and Hydrocarbon Accumulation in Sedimentary Basin," Marine Origin Petroleum Geology, vol. 01, pp. 37-42, 2005, [In Chinese with English abstract].

[3] X. N. Xie, J. M. Cheng, and Y. L. Meng, "Basin fluid flow and associated diagenetic processes," Acta Sedimentologica Sinica, vol. 05, pp. 863-871, 2009, [In Chinese with English abstract].

[4] S. T. Paxton, J. O. Szabo, J. M. Ajdukiewicz, and R. E. Klimentidis, "Construction of an intergranular volume compaction curve for evaluating and predicting compaction and porosity 
loss in rigid-grain sandstone reservoirs," AAPG Bulletin, vol. 86, no. 12 , pp. 2047-2067, 2002.

[5] S. J. Huang, H. W. Wu, J. Liu, L. C. Shen, and C. G. Huang, "Generation of secondary porosity by meteoric water during time of subaerial exposure: An example from Yanchang Formation sandstone of Triassic of Ordos Basin," Earth Science, vol. 04, pp. 419-424, 2003, [In Chinese with English abstract].

[6] M. A. K. El-ghali, H. Mansurbeg, S. Morad, I. Al-Aasm, and G. Ajdanlisky, "Distribution of diagenetic alterations in fluvial and paralic deposits within sequence stratigraphic framework: evidence from the Petrohan Terrigenous Group and the Svidol Formation, Lower Triassic, NW Bulgaria," Sedimentary Geology, vol. 190, no. 1-4, pp. 299-321, 2006.

[7] M. P. Verma, "Qrtzgeotherm: An ActiveX component for the quartz solubility geothermometer," Computers \& Geosciences, vol. 34, no. 12, pp. 1918-1925, 2008.

[8] A. Berger, S. Gier, and P. Krois, "Porosity-preserving chlorite cements in shallow-marine volcaniclastic sandstones: Evidence from cretaceous sandstones of the sawan gas field, Pakistan," AAPG Bulletin, vol. 93, no. 5, pp. 595-615, 2009.

[9] K. Bjørlykke, M. Ramm, and G. C. Saigal, "Sandstone diagenesis and porosity modification during basin evolution," Geologische Rundschau, vol. 78, no. 1, pp. 243-268, 1989.

[10] K. Bjørlykke, "Fluid flow in sedimentary basins," Sedimentary Geology, vol. 86, no. 1-2, pp. 137-158, 1993.

[11] K. Bjørlykke and J. Jahren, "Open or closed geochemical systems during diagenesis in sedimentary basins: Constraints on mass transfer during diagenesis and the prediction of porosity in sandstone and carbonate reservoirs," AAPG Bulletin, vol. 96, no. 12, pp. 2193-2214, 2012.

[12] G. Yuan, Y. Cao, T. Yang et al., "Porosity enhancement potential through mineral dissolution by organic acids in the diagenetic process of clastic reservoir," Earth Science Frontiers, vol. 20, no. 5, pp. 207-219, 2013.

[13] G.-H. Yuan, Y.-C. Cao, Z.-Z. Jia, Y.-Z. Wang, and T. Yang, "Research progress on anomalously high porosity zones in deeply buried clastic reservoirs in petroliferous basin," Natural Gas Geoscience, vol. 26, no. 1, pp. 28-42, 2015.

[14] X. Q. Ding, M. M. Han, S. N. Zhang, M. Y. Fu, and Y. L. Wan, "Roles of meteoric water on secondary porosity of siliciclastic reservoirs," International Geology Review, vol. 60, pp. 145-158, 2014, [In Chinese with English abstract].

[15] A. Putnis, "Transient porosity resulting from fluid-mineral interaction and its consequences," Reviews in Mineralogy and Geochemistry, vol. 80, no. 1, pp. 1-23, 2015.

[16] Z. Cao, G. Liu, Y. Kong et al., "Lacustrine tight oil accumulation characteristics: Permian Lucaogou Formation in Jimusaer Sag, Junggar Basin," International Journal of Coal Geology, vol. 153, pp. 37-51, 2016.

[17] M. H. Liu and C. L. Zhao, "Review of the studies on oil and gas reservoirs," Journal of China University of Petroleum, vol. 15, pp. 115-124, 1991, [In Chinese with English abstract].

[18] P. Luo, Y. N. Qiu, A. L. Jia, and X. S. Wang, “The Present Challenges of Chinese Petroleum Reservoir Geology and Research Direction," Acta Sedimentologica Sinica, vol. 21, pp. 142-147, 2003, [In Chinese with English abstract].

[19] S. N. Ehrenberg, P. H. Nadeau, and Ø. Steen, "A megascale view of reservoir quality in producing sandstones from the offshore Gulf of Mexico," AAPG Bulletin, vol. 92, no. 2, pp. 145-164, 2008.

[20] S. N. Ehrenberg, P. H. Nadeau, and $\varnothing$. Steen, "Petroleum reservoir porosity versus depth: Influence of geological age," AAPG Bulletin, vol. 93, no. 10, pp. 1281-1296, 2009.
[21] C.-L. Ye, G.-D. Zheng, and J. Zhao, "Research review of WaterRock interactions in reservoir rocks," Bulletin of Mineralogy Petrology and Geochemistry, vol. 29, no. 1, pp. 89-97, 2010.

[22] J. M. Ajdukiewicz and R. H. Lander, "Sandstone reservoir quality prediction: the state of the art," AAPG Bulletin, vol. 94, no. 8, pp. 1083-1091, 2010.

[23] T. R. Taylor, M. R. Giles, L. A. Hathon et al., "Sandstone diagenesis and reservoir quality prediction: models, myths, and reality," AAPG Bulletin, vol. 94, no. 8, pp. 1093-1132, 2010.

[24] R. C. Tobin, T. McClain, R. B. Lieber et al., "Reservoir quality modeling of tight-gas sands in Wamsutter field: integration of diagenesis, petroleum systems, and production data," $A A P G$ Bulletin, vol. 94, no. 8, pp. 1229-1266, 2010.

[25] J. Lai, G. Wang, Y. Ran, Z. Zhou, and Y. Cui, "Impact of diagenesis on the reservoir quality of tight oil sandstones: The case of Upper Triassic Yanchang Formation Chang 7 oil layers in Ordos Basin, China," Journal of Petroleum Science and Engineering, vol. 145, pp. 54-65, 2016.

[26] Z. Cao, G. D. Liu, W. Meng, P. Wang, and C. Y. Yang, “Origin of different chlorite occurrences and their effects on tight clastic reservoir porosity," Journal of Petroleum Science Engineering160, pp. 384-392, 2017.

[27] R. C. Surdam and P. Yin, "Organic Acids and Carbonate Stability, the Key to Predicting Positive Porosity Anomalies," in in. Organic Acids in Geological Processes, Pittman E. D. and M. D. Lewan, Eds., pp. 398-448, Springer, Berlin, Germany, 1994.

[28] S. M. C. D. Anjos, L. F. D. Ros, R. S. D. Souza, C. M. D. A. Silva, and C. L. Sombra, "Depositional and diagenetic controls on the reservoir quality of Lower Cretaceous Pendência sandstones, Potiguar rift basin, Brazil," AAPG Bulletin, vol. 84, 2000.

[29] P. Gouze and A. Coudrain-Ribstein, "Chemical reactions and porosity changes during sedimentary diagenesis," Applied Geochemistry, vol. 17, no. 1, pp. 39-47, 2002.

[30] J. M. Ketzer, M. Holz, S. Morad, and I. S. Al-Aasm, "Sequence stratigraphic distribution of diagenetic alterations in coalbearing, paralic sandstones: evidence from the Rio Bonito Formation (early Permian), southern Brazil," Sedimentology, vol. 50, no. 5, pp. 855-877, 2003.

[31] S. J. Huang, K. K. Huang, L. W. Feng, H. P. Tong, L. H. Liu, and X. H. Zhang, "Mass exchanges among feldspar, kaolinite and illite and their influences on secondary porosity formation in clastic diagenesis - a case study on the Upper Paleozoic, Ordos Basin and Xujiahe Formation, Western Sichuan Depression," Geochimica, vol. 38, pp. 498-506, 2009, [In Chinese with English abstract].

[32] H. Mansurbeg, M. A. K. El-ghali, S. Morad, and P. PlinkBjörklund, "The impact of meteoric water on the diagenetic alterations in deep-water, marine siliciclastic turbidites," Journal of Geochemical Exploration, vol. 89, no. 1-3, pp. 254-258, 2006.

[33] B. S. Yu and X. Y. Lai, "Dissolution of calcite cement and its contribution to the secondary pores of reservoir in the kela2 gas field in the Tarim basin," Journal of Mineralogy and Petrology, vol. 26, pp. 74-79, 2006, [In Chinese with English abstract].

[34] Z. Cao, G. Liu, H. Zhan et al., "Pore structure characterization of Chang-7 tight sandstone using MICP combined with $\mathrm{N}^{2}$ GA techniques and its geological control factors," Scientific Reports, vol. 6, Article ID 36919, 2016.

[35] G. Yuan, J. Gluyas, Y. Cao et al., "Diagenesis and reservoir quality evolution of the Eocene sandstones in the northern Dongying Sag, Bohai Bay Basin, East China," Marine and Petroleum Geology, vol. 62, pp. 77-89, 2015. 
[36] Y. Li, J. G. Cai, and J. M. Liu, "High-resolution sequence stratigraphy of paleogene in Dongying Depression," Acta Sedimentologica Sinica, vol. 20, pp. 212-213, 2002, [In Chinese with English abstract].

[37] I. Friedma and O’Neil. Jr, “Compilation of stable isotope fractionation factors of geochemical interest," in in. Data of Geochemistry, M. Fleischer, Ed., p. 114, Geological Survey, USA, 6 edition, 1977.

[38] P. Deines, "The isotopic composition of reduced organic carbon," in in. Handbook of Environmental Isotope Geochemistry, P. Fritz and J. C. Fontes, Eds., pp. 329-406, Elsevier, Amsterdam, The Netherlands, 1980.

[39] S. M. Savin, "Oxygen and hydrogen isotope effects in low-temperature mineral-water interactions," in In : Handbook of environmental isotope geochemistry, P. Fritz and J. C. Fontes, Eds., pp. 283-327, Elsevier, Amsterdam, The Netherlands, 1980.

[40] K. Kelts and M. Talbot, "Lacustrine Carbonates as Geochemical Archives of Environmental Change and Biotic/Abiotic Interactions," in Large Lakes, Brock/Springer Series in Contemporary Bioscience, pp. 288-315, Springer Berlin Heidelberg, Berlin, Heidelberg, 1990.

[41] J. Veizer, D. Ala, K. Azmy et al., " ${ }^{87} \mathrm{Sr} /{ }^{86} \mathrm{Sr}, \delta^{13} \mathrm{C}$ and $\delta^{18} \mathrm{O}$ evolution of Phanerozoic seawater," Chemical Geology, vol. 161, no. 1, pp. 59-88, 1999.

[42] D. Ala, K. Azmy, P. Bruckschen et al., " ${ }^{87} \mathrm{Sr} /{ }^{86} \mathrm{Sr}, \delta^{13} \mathrm{C}$ and $\delta^{18} \mathrm{O}$ evolution of Phanerozoic seawater," Chemical Geology, vol. 161, no. 1, pp. 1586-1586, 1999.

[43] M. Fayek, T. M. Harrison, M. Grove, K. D. McKeegan, C. D. Coath, and J. R. Boles, "In situ stable isotopic evidence for protracted and complex carbonate cementation in a petroleum reservoir, north coles levee, san joaquin basin, California, U.S.A," Journal of Sedimentary Research, vol. 71, no. 3, pp. 444458, 2001.

[44] S. G. Franks, R. F. Dias, K. H. Freeman et al., "Carbon isotopic composition of organic acids in oil field waters, San Joaquin Basin, California, USA," Geochimica et Cosmochimica Acta, vol. 65, no. 8, pp. 1301-1310, 2001.

[45] S. Liu, S. Huang, Z. Shen, Z. Lü, and R. Song, "Diagenetic fluid evolution and water-rock interaction model of carbonate cements in sandstone: An example from the reservoir sandstone of the Fourth Member of the Xujiahe Formation of the Xiaoquan-Fenggu area, Sichuan Province, China," Science China Earth Sciences, vol. 57, no. 5, pp. 1077-1092, 2014.

[46] B. Wu, A. Wei, C. Liu et al., "Stable isotope tracing on the formation of white sandstone in Yan'an Group, northern Ordos Basin, and its geological significance," Earth Science Frontiers, vol. 22, no. 3, pp. 205-214, 2015.

[47] S. X. Shao, J. H. Zeng, S. W. Zhang et al., "Types, characteristics and origin of kaolinite in sandstone reservoir of Shahejie Formation, Dongying Sag," Acta Sedimentologica Sinica, vol. 33, pp. 1204-1216, 2015, [In Chinese with English abstract].

[48] A. Matthews and A. Katz, "Oxygen isotope fractionation during the dolomitization of calcium carbonate," Geochimica et Cosmochimica Acta, vol. 41, no. 10, pp. 1431-1438, 1977.

[49] C. L. Liu, "Carbon and oxygen isotopic compositions of lacustrine carbonates of the Shahejie Formation in the Dongying depression and their paleolimnological significance," Acta Sedimentologica Sinica, vol. 16, pp. 109-114, 1998, [In Chinese with English abstract].

[50] N. Qiu, S. Li, and J. Zeng, “Thermal history and tectonic-thermal evolution of the Jiyang depression in the Bohai Bay Basin,
East China," Acta Geologica Sinica, vol. 78, no. 2, pp. 263-269, 2004.

[51] X. C. Lu, W. X. Hu, Q. Fu et al., "Study of salinity evolution of geofluids during syngenesis and diagenesis using composition of carbonate minerals," Acta Sedimentologica Sinica, vol. 16, pp. 120-126, 1998, [In Chinese with English abstract].

[52] J. H. Zeng, J. L. Peng, N. S. Qiu, and Z. Q. Zhu, "Carbonate dissolution-precipitation in sandstone-shale contact and its petroleum geological meanings," Natural Gas Geoscience, vol. 06, pp. 760-764, 2006, [In Chinese with English abstract].

[53] S. Zhang, L. Zhang, S. Zhang, Q. Liu, R. Zhu, and Y. Bao, "Formation of abnormal high pressure and its application in the study of oil-bearing property of lithologic hydrocarbon reservoirs in the Dongying Sag," Chinese Science Bulletin, vol. 54, no. 23, pp. 4468-4478, 2009.

[54] J. Guo, J. H. Zeng, G. Q. Song, Y. W. Zhang, X. J. Wang, and W. Meng, "Characteristics and Origin of Carbonate Cements of Shahejie Formation of Central Uplift Belt in Dongying Depression," Earth Science, vol. 39, pp. 565-576, 2014, [In Chinese with English abstract].

[55] Y. W. Zhang, J. H. Zeng, X. Gao, and S. Y. Zhou, "Distribution characteristics and main controlling Factors of carbonate cements in the paleogene reservoirs in Dongying Depression," Journal of Jilin University, vol. 39, pp. 16-22, 2009, [In Chinese with English abstract].

[56] H. O. Cookenboo and R. M. Bustin, "Pore water evolution in sandstones of the Groundhog Coalfield, northern Bowser Basin, British Columbia," Sedimentary Geology, vol. 123, no. 12, pp. 129-146, 1999.

[57] N. R. Goulty, C. Sargent, P. Andras, and A. C. Aplin, "Compaction of diagenetically altered mudstones - Part 1: Mechanical and chemical contributions," Marine and Petroleum Geology, vol. 77, pp. 703-713, 2016.

[58] J. Zhao, "Laws of mudstone compaction on the west slope of the Songliao Basin," Oil and Gas Geology, vol. 31, pp. 486-492, 2010, [In Chinese with English abstract].

[59] Y. J. Han, S. He, G. Q. Song et al., "Origin of carbonate cements in the overpressured top seal and adjacent sandstones in Dongying depression," Petroleum Processing Section, vol. 33, pp. 385-393, 2012, [In Chinese with English abstract].

[60] R. C. Surdam, L. J. Crossey, E. S. Hagen, and H. P. Heasler, "Organic-inorganic interactions and sandstone diagenesis," The American Association of Petroleum Geologists Bulletin, vol. 73, no. 1, pp. 1-23, 1989.

[61] D. K. Zhong, X. M. Zhu, and J. G. Cai, "Vertical distribution of secondary pores in Paleogene sandstones in Zhanhua Depression," Oil and Gas Geology, vol. 24, pp. 286-290, 2003, [In Chinese with English abstract].

[62] G. R. Davies and L. B. Smith Jr., "Structurally controlled hydrothermal dolomite reservoir facies: an overview," AAPG Bulletin, vol. 90, no. 11, pp. 1641-1690, 2006.

[63] B. J. Wang, S. He, and J. Wang, "Hydrochemistry field origin and its coupling relationship with overpressure system, Dongying depression," Journal of China University of Petroleum, vol. 36, pp. 54-64, 2012, [In Chinese with English abstract].

[64] R. Shiraki and T. L. Dunn, "Experimental study on water-rock interactions during $\mathrm{CO} 2$ flooding in the Tensleep formation, Wyoming, USA," Applied Geochemistry, vol. 15, no. 3, pp. 265$279,2000$.

[65] Y. Zhang, J. Zeng, Z. Qu, and J. Chen, "Development characteristics and genetic mechanism of authigenic kaolinite in 
sandstone reservoirs of the Dongying Sag, Bohai Bay Basin," Oil and Gas Geology, vol. 36, no. 1, pp. 73-79, 2015.

[66] Q. P. Che and H. B. Sun, "Authigenic kaolinite orign analysis of paleogene sandstone reservoirs in Niuju area," Journal of Changchun University of science and Technology, vol. 25, pp. 306-309, 1995, [In Chinese with English abstract].

[67] J. Y. Gu and B. He, "Study on triassic fin delta sedimention and reservoir in Lunnan Area Tarim basin," Acta Sedimentologica Sinica, vol. 12, pp. 54-62, 1994, [In Chinese with English abstract].

[68] X. Y. Zhao, "The conditions for formation of kaolinite subgroup in Tarim Basin," Xinjiang Petroleum Geology, vol. 24, pp. 419423, 2003, [In Chinese with English abstract].

[69] H. Y. Zou, F. Hao, G. D. Liu, and C. Sui, "Genesis of authigenic kaolinite and gas accumulation in Bashijiqike Fm sandstone in Kuqa thrust belt," Oil and Gas Geology, vol. 26, pp. 786-791, 2005, [In Chinese with English abstract].

[70] J. Cao, Y. J. Zhang, H. u. WX et al., "Developing characteristics of kaolinite in central Junggar Basin and their effect on the reservoir quality," Acta Mineralogica Sinica, vol. 25, pp. 367-373, 2005, [In Chinese with English abstract].

[71] X. Chen, J. Zhong, J. Yuan, K. Nie, and Y. Yang, "Development and formation of Paleogene kaolinite, Bonan subsag," Shiyou Kantan Yu Kaifa/Petroleum Exploration and Development, vol. 36, no. 4, pp. 456-462, 2009.

[72] H. Irwin and A. Hurst, "Applications of geochemistry to sandstone reservoir studies," Geological Society, London, Special Publications, vol. 12, pp. 127-146, 1983.

[73] W. J. Fu and W. B. Liu, "Study on the alteration of feldspar from clastic rock in Tarim Basin," Acta Sedimentologica Sinica, pp. 84-89, 1996, [In Chinese with English abstract].

[74] J. H. Zeng, "Effect of fluid-rock interaction on porosity of reservoir rocks in Tertiary System, Dongying Sag," Shiyou Xuebao/Acta Petrolei Sinica, vol. 22, no. 4, p. 39, 2001.

[75] J. Tóth, "Cross-formational gravity-flow of groundwater: A mechanism of the transport and accumulation of petroleum (the generalized hydraulic theory of petroleum migration)," in in: Problems of petroleum migration, I. Roberts and R. J. Cordell, Eds., pp. 121-167, AAPG Studies in Geology, USA, 1980.

[76] M. Zha, "The dynamic models and numerical simulation of secondary petroleum migration in compactional flow basins an example from the Dong Ying Depression," Acta Sedimentologica Sinica, vol. 15, pp. 86-90, 1997, [In Chinese with English abstract].

[77] K. Bjørlykke, "Relationships between depositional environments, burial history and rock properties. Some principal aspects of diagenetic process in sedimentary basins," Sedimentary Geology, vol. 301, pp. 1-14, 2014.

[78] E. H. Oelkers and J. Schott, "Experimental study of anorthite dissolution and the relative mechanism of feldspar hydrolysis," Geochimica et Cosmochimica Acta, vol. 59, no. 24, pp. 50395053, 1995.

[79] J. S. Jahren and P. Aagaard, "Compositional variations in diagenetic chlorites and illites, and relationships with formationwater chemistry," Clay Minerals, vol. 24, no. 2, pp. 157-170, 1989.

[80] C. L. Liu, H. Q. Zhao, and P. X. Wang, "Water Chemistry of the Paleogene Dongying Lake: Evidence from Fossil Assemblages and Shell Isotopes," Acta Geoscientia Sinica, vol. 23, pp. 237-242, 2002, [In Chinese with English abstract].

[81] Z. H. Chen, M. Zha, and Q. Jin, "Mineral elemental response to the evolution of terrestrial Brine faulted-basin: a case study in the Paleogene of Well Haoke-1, Dongying Sag," Acta Sedimentologica Sinica, vol. 26, pp. 925-932, 2008, [In Chinese with English abstract].

[82] B. N. Popp and B. H. Wilkinson, "Holocene lacustrine ooids from Pyramid lake, Nevada," in In: Coated Grains, T. Peryt, Ed., pp. 141-153, Springer-Verlag, Berlin, Germany, 1983.

[83] P. A. Sandberg, "New interpretations of Great Salt Lake ooids and of ancient non-skeletal carbonate mineralogy," Sedimentology, vol. 22, no. 4, pp. 497-537, 1975. 

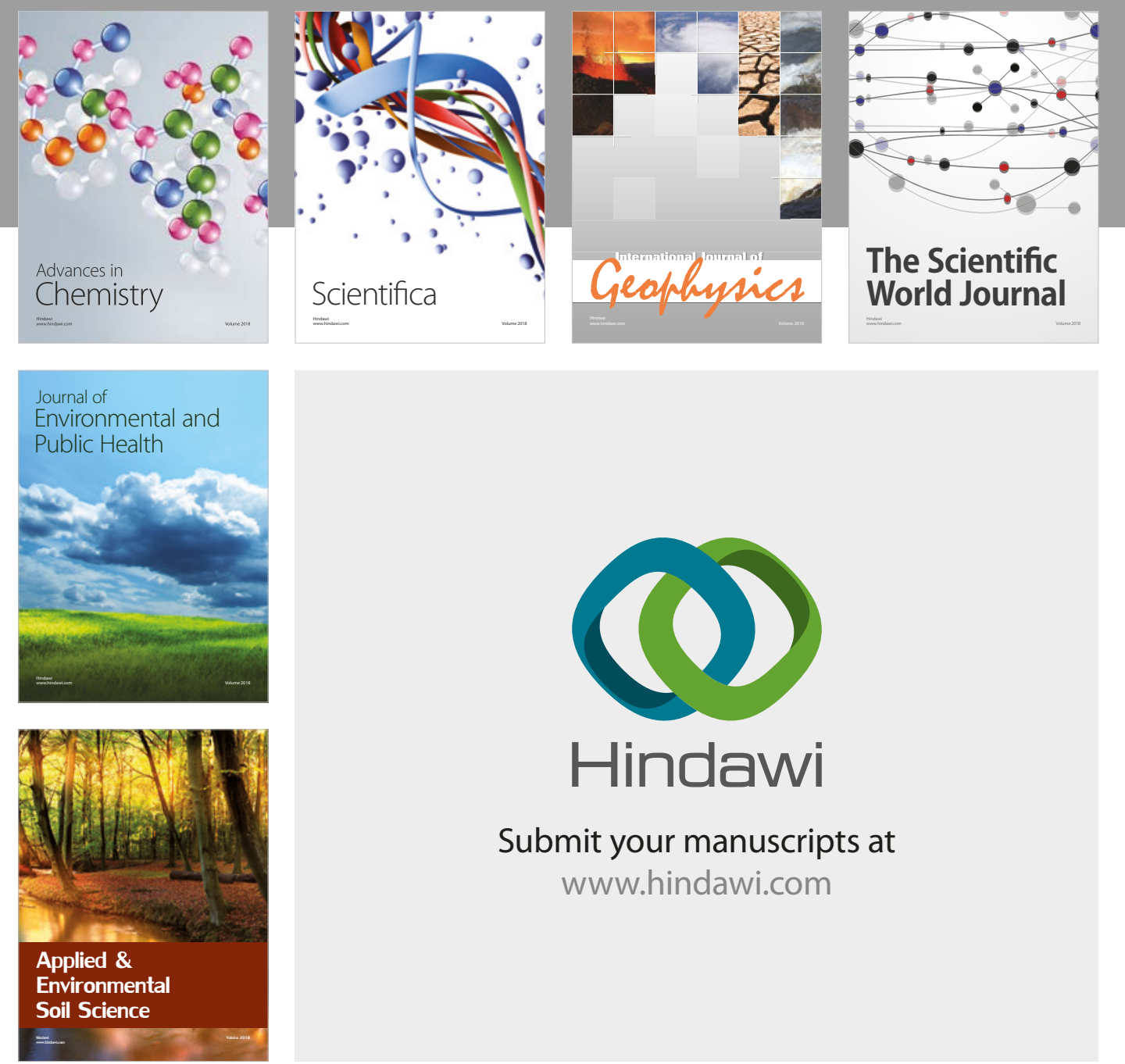

The Scientific

\section{World Journal}
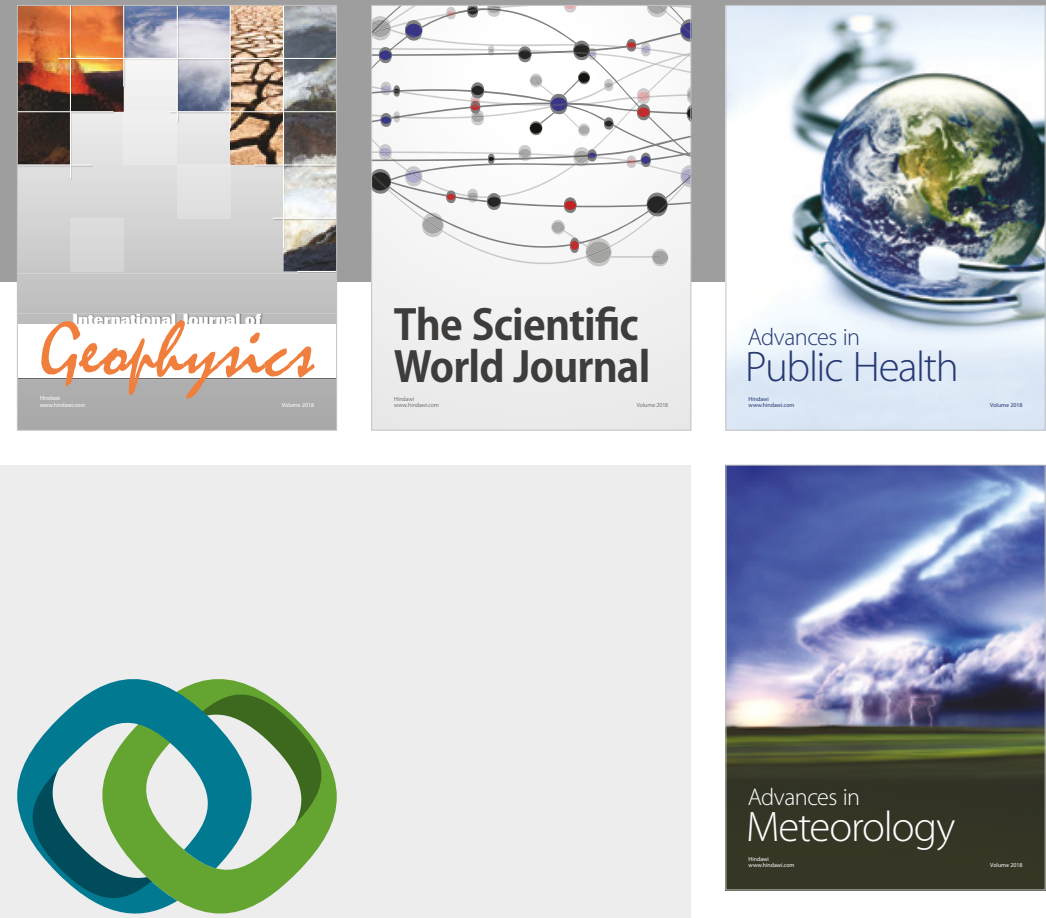

Advan

Public Health

\section{Hindawi}

Submit your manuscripts at

www.hindawi.com
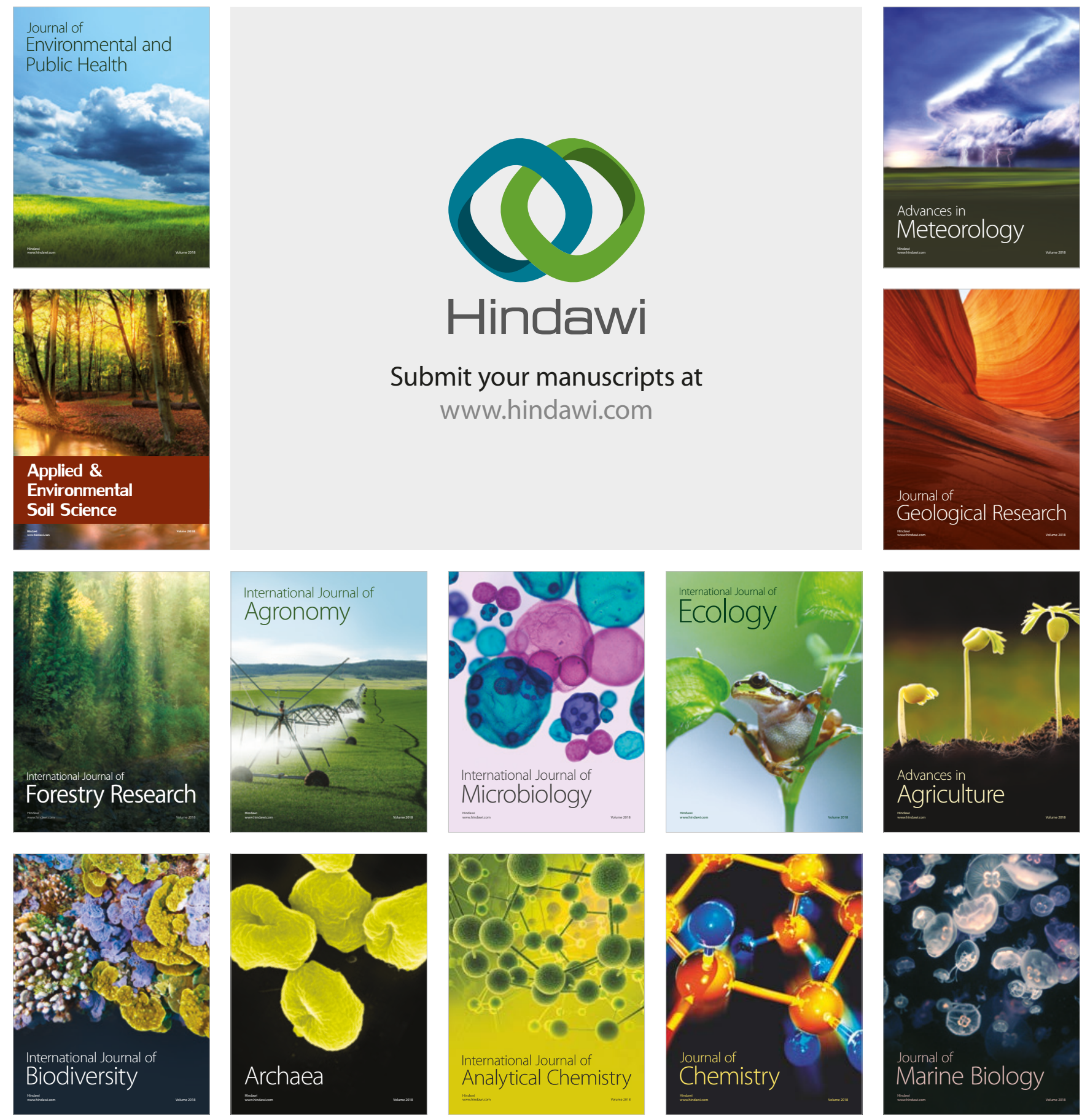